\title{
Water Conservation and Plant Survival Strategies of Rhizobacteria under Drought Stress
}

\author{
Naeem Khan ${ }^{1, *(\mathbb{D}}$, Shahid Ali ${ }^{2}{ }^{(\mathbb{D}}$, Haleema Tariq ${ }^{3}$, Sadia Latif ${ }^{4,5}$, Humaira Yasmin ${ }^{6}$, \\ Asif Mehmood ${ }^{7}$ and Muhammad Adnan Shahid ${ }^{8}$ \\ 1 Department of Agronomy, Institute of Food and Agricultural Sciences, University of Florida, \\ Gainesville, FL 32611, USA \\ 2 Plant Epigenetic and Development, Northeast Forestry University, Harbin 150040, China; \\ Shahidsafi926@gmail.com \\ 3 Department of Biosciences, University of Wah, Wah Cantt 47040, Pakistan; haleema.tariq2020@gmail.com \\ 4 Department of Plant Sciences, Quaid-i-Azam University, Islamabad 45320, Pakistan; slatif@bs.qau.edu.pk \\ 5 Department of Biology and Environmental Science, Allama Iqbal Open University, Islamabad 44000, Pakistan \\ 6 Department of Bio-Sciences, COMSATS University, Islamabad 45550, Pakistan; \\ humaira.yasmin@comsats.edu.pk \\ 7 Institute of Biological Sciences, Sarhad University of Science and Information Technology, \\ Peshawar 25000, Pakistan; asif.ibs@suit.edu.pk \\ 8 Department of Agriculture, Nutrition and Food Systems, University of New Hampshire, \\ Durham, NH 03824, USA; muhammad.shahid@unh.edu \\ * Correspondence: naeemkhan@ufl.edu or naeemkhan001@gmail.com
}

Received: 18 September 2020; Accepted: 28 October 2020; Published: 30 October 2020

check for updates

\begin{abstract}
Drylands are stressful environment for plants growth and production. Plant growth-promoting rhizobacteria (PGPR) acts as a rampart against the adverse impacts of drought stress in drylands and enhances plant growth and is helpful in agricultural sustainability. PGPR improves drought tolerance by implicating physio-chemical modifications called rhizobacterial-induced drought endurance and resilience (RIDER). The RIDER response includes; alterations of phytohormonal levels, metabolic adjustments, production of bacterial exopolysaccharides (EPS), biofilm formation, and antioxidant resistance, including the accumulation of many suitable organic solutes such as carbohydrates, amino acids, and polyamines. Modulation of moisture status by these PGPRs is one of the primary mechanisms regulating plant growth, but studies on their effect on plant survival are scarce in sandy/desert soil. It was found that inoculated plants showed high tolerance to water-deficient conditions by delaying dehydration and maintaining the plant's water status at an optimal level. PGPR inoculated plants had a high recovery rate after rewatering interms of similar biomass at flowering compared to non-stressed plants. These rhizobacteria enhance plant tolerance and also elicit induced systemic resistance of plants to water scarcity. PGPR also improves the root growth and root architecture, thereby improving nutrient and water uptake. PGPR promoted accumulation of stress-responsive plant metabolites such as amino acids, sugars, and sugar alcohols. These metabolites play a substantial role in regulating plant growth and development and strengthen the plant's defensive system against various biotic and abiotic stresses, in particular drought stress.
\end{abstract}

Keywords: PGPR; RIDER; drylands; water conservation

\section{Introduction}

Desertification, drought, and land degradation are major challenges to sustainable crop production throughout the world especially in developed countries. Water scarcity mainly due to low annual precipitation is very damaging for plant growth, and ultimately sustainable crop production. However, 
there is an inordinate need to use these areas even with marginal productivity due to damage to basic farmlands. Therefore, there is more interest in producing crops using low or marginal yields of soil (e.g., sandy soil) [1]. However, sandy soil has high temperatures and suffers severe drought. Stress losses can range from $50 \%$ to $80 \%$, depending on the stress period and type of plant species [2]. Drought stress in desert areas affects plant water potential, restricts the normal plant performance, [3], and alters the plant physiological and morphological characteristics [4,5]. Drought stress-induced plant growth was studied in wheat [6], barley [7], rice, and corn [8]. Moisture content and plant biomass are common growth factors impacted by drought stress in these plants [9]. Besides, drought stress stimulus negatively impacts the nutrient uptake and translocation as the soil nutrients are transferred to the roots via water.

Consequently, drought stress reduces the absorption of nutrient and mass-flux of water-soluble nutrients, for example, calcium, nitrate, sulfate, silicon, and magnesium [10]. Drought stress enhances formation of free radicals that damage plant defence system resulting in an increase in reactive oxygen species (ROS), such as superoxide radicals, hydroxyl radicals, and hydrogen peroxide induces oxidative stress. ROS can cause tissue damage, to membrane corrosion, proteins and nucleic acids by causing their lipid peroxidation [11-13].

Water stress is responsible for high economic losses in arid and semi-arid regions. It disturbs plant-water relations at cellular and whole plant levels, resulting in specific and non-specific responses [14]. Plant reaction to water stress is a complex process that tends to include polyamine formation and a collection of novel proteins with relatively unknown functions. Drought decreases the photosynthesis supply of carbon dioxide, which may contribute to ROS production from misguided electrons in the camera system $[15,16]$. It also creates free radicals during abiotic tension. ROS, such as radical superoxide $\left(\mathrm{O}_{2}^{-}\right)$, radical hydroxyl $(\mathrm{OH})$, and hydrogen peroxide, enhance the damaging effect of lipid peroxidation throughout the membrane [17]. Plants have an antioxidant defensive system which prevents cellular membranes and DNA from ROS-induced oxidative damage by converting ROS into non-toxic forms such as water and oxygen $[18,19]$.

Inoculation of plants with growth-promoting microorganisms can improve water retention strategies and drought tolerance of plants grown in arid or semi-arid regions [20]. These useful microbes inhabit the rhizosphere/endogenous rhizosphere of the plant through various direct-indirect mechanisms and promote plant growth (Figure 1). The rhizosphere is a thin layer of soil surrounding the roots of the plant and is a very critical and active area of root activity and metabolism [21-23]. A significant number of microorganisms coexist in the rhizosphere, such as bacteria, fungi, protozoa, and algae, but mostly different types of bacteria. Plants release organic compounds through exudate to select the bacteria that contribute most to the plant's health under stressful conditions [24]. The beneficial relationships of plant-microbes in the rhizosphere are the key determinants in water conservation, soil productivity, and plant health. Plant growth-promoting rhizobacteria (PGPR) affect growth, yield, and nutrient uptake through a series of mechanisms. Some strains (e.g., Azospirillum brasilense, Aeromonas punctata, Bacillus megaterium, Pseudomonas fluorescens, Serratia marcescens) directly modulate plant physiology by stimulating the production of plant hormones, while others upturn minerals and nitrogen in the soil as a means of increasing growth under water-deficient conditions [25-28].

The current review comprehensively covers major research to evaluate the effectiveness of PGPR in alleviating crop water stress and to find effective PGPR to help crops in maintaining water status under drought conditions. The aim of the present review is to provide insights into the role of phytohormones, plant metabolites, exopolysaccharides (EPS), and 1-aminocyclopropane-1-caroboylic acid (ACC) deaminase activity in stress tolerance of plants in response to PGPR inoculation. This review identifies the challenges of drought stress and involvement of PGPR in the mitigation of drought stress in plants for sustainable production. 


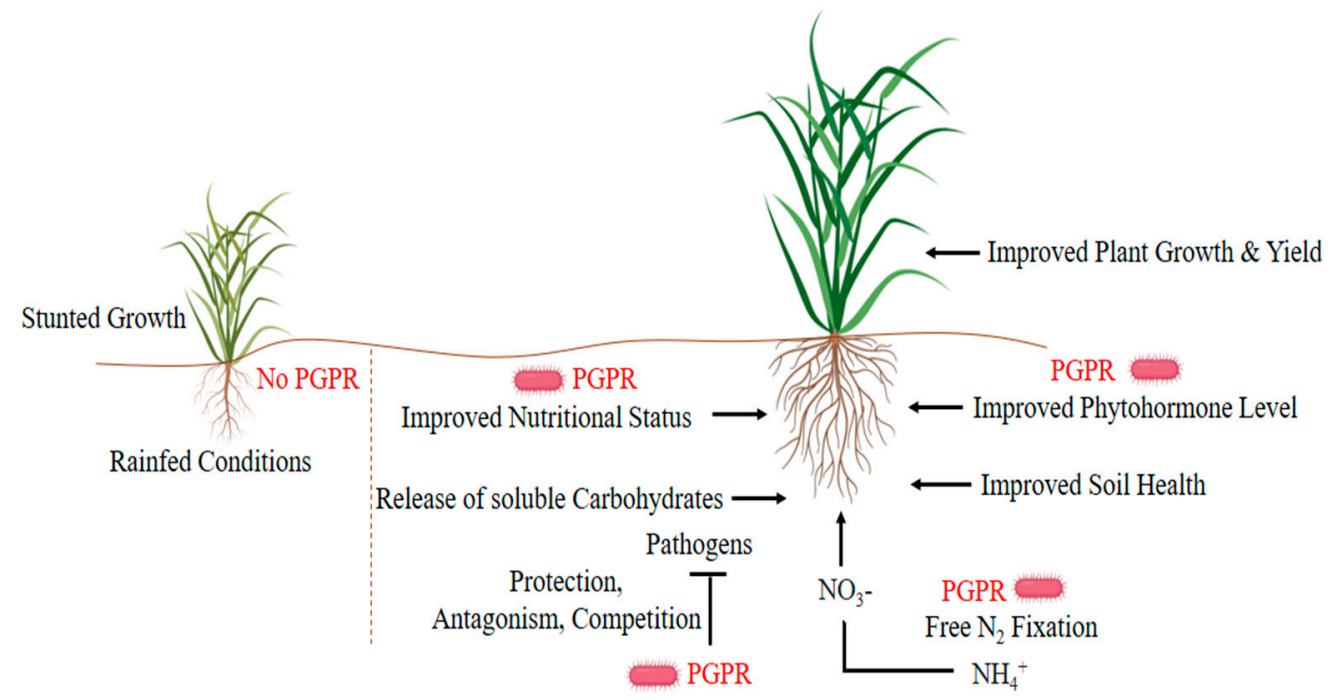

Figure 1. Plant growth-promoting strategies of plant growth-promoting rhizobacteria (PGPR) under drought stress.

\section{Plant Survival Strategies under Drought Stress}

A species may have a complementary set of survival strategies enabling it to survive under small and unpredictable distribution of rain [29]. Desert plants may have no water for many years. Plants exhibit different responses when sensing abiotic stimuli, which are related to specific stress-tolerance mechanisms [30-32]. A series of epidermis waxes protect plants from excessive moisture loss and provide protection against various pathogenic antagonistic activities [33]. In addition, osmoprotectants like proline accumulation aid in sustaining the plant's water potential, and promotes the plant's extraction of water from the soil [34]. Changes in primary metabolism are considered to be the most obvious of all metabolic reactions and comprise changes in the level of sugar/sugar alcohol, amino acid, and tricarboxylic acid cycle intermediates, exhibiting a common tendency for ecological stress reactions. However, changes in secondary metabolism are exact to particular stress and are precise to the type of plant species [35,36].

Some of the metabolic compounds that are associated with abiotic stresses and act as protectants include the sorbitol, polyols, mannitol, sucrose, fructan, proline, and ectoine [37]. Other small molecules such as carotenoids, ascorbic acid, tocopherols and anthocyanins also protect plants from being subjected to oxidative injury and protect plants by eliminating stress-induced ROS in plants. The production of phytoalexins and initiation of phenylpropanoid pathways and lignin biosynthesis are related to plant defence mechanisms [38-40]. Plant molecules such as salicylic acid, jasmonic acid, methyl salicylate, and methyl jasmonate are formed under stress. They can also act as signalling molecules that trigger defences against various biotic and abiotic stresses in crop plants [41]. In recent years, metabolomics has been used for various purposes, such as (1) assessing the effect of various stresses in plants; (2) pursuing the contribution of specific compounds in a specific biosynthetic or secondary deprivation pathway and (3) organizing various plant samples [42]. Stability, defence, and signalling of metabolites can be used to measure the degree of plant lenience to diverse abiotic stresses [43,44]. Extensive research is carried out to develop policies against drought stress by growing drought-tolerant crops, improving crop calendars and resource management practices [45]. 


\section{Water Conservation Strategies of Plant Growth-Promoting Rhizobacteria (PGPR)}

Using PGPR and commensal microorganisms, in particular arbuscular mycorrhiza (AM) fungi, may help to develop strategies to improve water retention potential in plants. More specifically, Pseudomonas sp. in the soil is of specific importance due to its versatility in catabolism, exceptional root colonization capacity, and the capability to produce a variety of enzymes and metabolites that contribute to abiotic stress tolerance in plants [46]. Relatively few pathways have been found to clarify the improved tolerance of Pseudomonas-treated plants to environmental stresses. Tolerance mechanisms such as increased osmotic adjustment and hydration of the leaves decreased oxidative damage, enhanced nutritional status, or increased the efficiency of intrinsic water usage have been suggested to elaborate the contribution of PGPR in improving stress tolerance [47].

Soil microbes have developed complex survival methods in desiccated soil. For example, bacteria have been documented to alter their membrane structure to improve their survival during the phases of low external water potential [48]. Increased water content in bacterial colonies can increase nutrient utilization [49]. In particular, the release of soluble carbohydrates in rhizosphere in PGPR-treated plants are higher, which can improving the survival rate of microorganisms under water deficit conditions. Some PGPR, such as Azospirillum, have the capacity to preserve water by developing cyst formation around the roots and by synthesizing polyhydroxybutyrate and melanin [50]. Likewise, extracellular bacterial polysaccharides will form organic mineral sheaths around cells along with surrounding mineral particles, which contributes to an improvement in development of macro-aggregates as an additional indirect consequence [51]. On the other hand, excessive drought stress decreases the amounts of water-soluble carbon and carbohydrates in rhizosphere of plants inoculated with Glomus intraradices, suggesting that mycorrhizal fungi serve as an effective sink for photosynthates and that these carbon fractions contribute to the stabilization of soil aggregates to a lesser extent. As a result, increased soil accumulation can be expected to increase water absorption by plants, thereby improving plant growth [52].

The free-moving soil bacteria sustain associations with the plant roots, thereby helping plant defence against various stresses, including drought, heavy metals toxicity, pathogens, and salinity [53-55]. Some PGPR such as Azospirillum sp., Pseudomonas fluorescens and Azotobacter sp. are widely used for increased crop yield $[56,57]$. The increased hydration caused by the PGPR strain could be due to improved water efficiency and/or enzymatic reduction of the concentration of plant ethylene, thus diminishing the inhibitory effect of ethylene on seedling root biomass [58]. The co-inoculation of arbuscular mycorrhizal fungi (Glomus intraradicers or Glomus mosseae) and PGPR Pseudomonas mendocina with Lactuca sativa L. improved antioxidant catalase under extreme drought conditions, indicating that inoculants can be used to mitigate oxidative damage induced by drought [59,60]. Kohler et al. [61] demonstrated that when PGPR, P. mendocina, and arbuscular mycorrhizal fungi were inoculated, antioxidant catalase activity was higher in lettuce plants under severe drought conditions. The aforementioned PGPR species were also found to be useful in reducing drought-induced oxidative damage in plants (Figure 2). Interestingly, the plant growth promoting bacteria (PGPB) strain Pseudomonas fluorescens Pf1 augmented enzymatic activities of catalase and peroxidase in green grams under water stress. Similarly, it can also serve as a storing compound for protein synthesis. Starch biosynthesis is reduced under stressed conditions, and proline accumulation is used as a carbon and nitrogen source for plant survival [62-65]. Other common mechanisms of maintaining water status by plants in response to PGPR under water stress are as follows: 


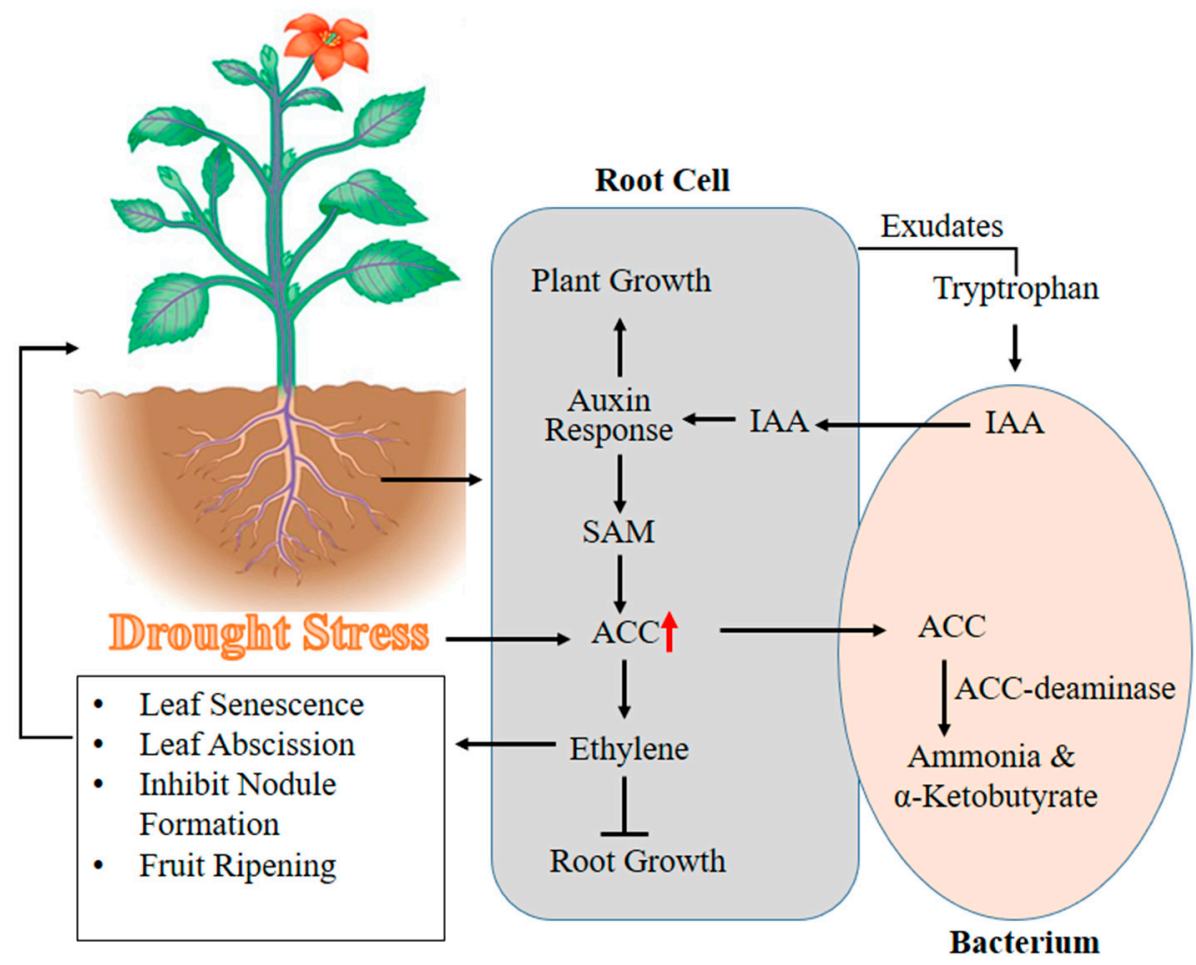

Figure 2. Water conservation and drought stress alleviating mechanisms employed by PGPR. SAM-Shoot apical meristem.

\subsection{Modifications in Phytohormones Content}

Plant growth-promoting rhizobacteria have developed various phytohormones, such as abscisic acid (ABA), ethylene, gibberellins, auxins, cytokinins and salicylic acid. Such hormones stimulate plant growth either directly or through certain secondary bacterial metabolites [66]. These plant hormones maintain plant water status water deficient conditions and are important for plant growth and disease prevention. Acetobacter, Bacillus, Herbaspirillum and Rhizobium species render gibberellins (Figure 2) [67]. Indole-3-acetic acid (IAA) is generated by some species of Micrococcus, Pseudomonas and Staphylococcus. Furthermore, cytokinins are produced by Azotobacter chroococcum that helps plants in sustaining proper moisture under extreme drought conditions [68]. The plant stress hormone abscisic acid (ABA), mediates plant stress tolerance by regulating several stress response genes and is responsible for maintaining proper moisture level in cells under drought conditions $[69,70]$. It has been previously reported that about $80 \%$ of the microorganisms extracted from the rhizosphere of different crops are recorded to be able to synthesize and release auxin as a secondary metabolite [71]. The rhizosphere bacteria-secreted IAA can interfere with plant growth and development, since receiving IAA from the soil bacteria may change the endogenous level of Plant IAA [72]. The IAA also serves as a signalling molecule that influences gene expression in a variety of microorganisms. The previous studies confirmed that phytohormones work as bi-directional communication between microbes and plant. For example, under nitrogen or phosphate starvation, the strigolactones exuded from the root, which attracts AM fungi, and downregulated their biosynthesis upon colonization [73]. Auxin and ABA have concentration-dependent positive effects on AM development while salicylic acid (SA), ethylene (ET), and gibrillic acid (GA) inhibit the root nodule and AM symbiosis. To understand the underlying complexity, it is essential to complement the genetics with system biology approaches, including hormone profiling, metabolomics, global network analysis, and computational molecular modeling of various processes in plants and soil. IAA is produced by many plant-associated microbes, including PGPR, nitrogen-fixing symbionts, and pathogens, which assist in interactions between plant-microbes $[74,75]$. The pathogenic bacteria that produce IAA, when grown in culture including 
Erwinia herbicola, Xanthomonas campestris, Erwinia Chrysanthemi, and several Pseudomonas syringae pathovars [76-79].

In plant-associated microbes, the IAA regulates the expression of genes that promote the interaction with plants. IAA induced large-scale changes in the transcriptome of PGPR, A. brasilense, which upregulate the gene expression involved in IAA biosynthesis and genes involved in the metabolism, respiration, and transportation [80]. These findings suggest that IAA promotes physiological and metabolic adjustment for growth in the rhizosphere [81]. Furthermore, IAA induces the expression of genes predicted to be involved in the Type VI secretion system (T6SS). In PGPR and other plant-associated bacteria, the role of the Type VI secretion is not well understood but may help the bacteria by injecting toxins into other microbes in the vicinity. Also, the exogenous IAA enhanced the expression of genes involved in stress responses. In Escherichia coli and Bradyhizobium japonicum the IAA treatments enhanced the cell viability when the bacteria was grown in stressful conditions, including oxidative stress, heat shock, and osmotic shock, and furthermore promoted biofilm production [82]. Consequently, IAA plays a very significant function in the relationship between rhizobacteria and plants [83]. Bacterial IAA can have enhanced the root length and surface area, making soil nutrients and water easier for plants to obtain. In addition, rhizobacteria IAA can relax plant cell walls, thereby increasing the root secretions and thus providing more nutrients to promote the growth of rhizosphere bacteria [84-87].

Agrobacterium tumefaciens strains STM196 isolated from the rhizosphere of rapeseed rape [88] have been shown to improve resistance to moderate water deficit, and alter plant physiology and delay developmental transition in Arabidopsis thaliana [89]. In addition, previous in vitro experiments have shown that STM196 modifies root architecture and hormonal signalling [90]. Importantly, STM196 not only improved plant longevity but also improved recovery of growth in living plants in post-stress and increased biomass production during flowering [91]. In A. thaliana, it was interpreted that the inculcation of Bacillus subtilis augmented the photosynthetic rate by reducing the concentration of ABA [92]. In the common bean, co-inoculation of Rhizobium tropici and Paenibacillus polymyxa has been shown to reduce the ABA content in water-deficient conditions [93]. The caronatine is exuded from Pseudomonas syringe, which inhibits the signalling pathways of ABA and prevents stomatal closure [94]. Arabidopsis thaliana inoculated with $A$. brasilense showed contrast results by increasing ABA content two-fold [95], and this increase in the content of ABA plays an important role in water conservation and alleviation of drought effects [96].

In addition to this, B. subtilis produces numerous polyamines which promote plant growth and development under water stress. The different types of polyamines, including spermine, spermidine, cadaverine and putrescine, are natural small-molecular-weight compound that modify physiological and biochemical attributes in plants and improve plant growth and development under drought environments [97]. Polyamine functions in the regulation of plant growth and water conservation. It has been reported to play a significant role both in promoting active growth and the division of cells into young tissues of the plants [98]. Polyamines promote the growth and cell differentiation in plant roots and provide insight into morphological variations [21,99]. Furthermore, they also play a major role in sustaining optimal ionic and $\mathrm{pH}$ environments, cell differentiation, organ development and secondary metabolite production under stress [100]. Polyamine has previously been documented to assist in stress tolerance either by regulating ROS homeostasis or by regulating antioxidant processes or by suppressing ROS production [101,102].

\subsection{PGPR Mediated Metabolites Involved in Drought Stress Tolerance}

Genetically engineered rhizobacteria, which overproduce trehalose in their cells, thereby allow plants to retain their water status and may increase survival of plants under extreme water-deficient conditions, in particular by increasing leaf water contents or by causing an accumulation of trehalose in the soil [103]. Some sugars including galactinol and raffinose act as osmoprotectants, which are synthesized in response to water-deficient conditions, mannitol scraps ROS, hydroxyl radicals and 
stabilize the structure of the enzyme [104,105]. The osmolytes prevent the creation of intramolecular hydrogen bonds in macromolecules by forming hydrogen bonds with them. Trehalose stabilizes the formation of membranes and macromolecules during water stress conditions and allows plants to retain water under harsh conditions. During different environmental pressures, the aggregation of different osmolytes such as glycinebetaines, proline, ectoine, etc. has been reported [106]. Similarly, Khan et al. [107] reported a different accumulation of metabolites such as L-proline, L-arginine, L-histidine, L-isoleucine, and tryptophan in chickpea cultivars grown under drought conditions (Figure 3). Furthermore, other metabolites like alanine, choline, phenylalanine, tyrosine, glucosamine, guanine gamma-aminobutyric acid, and aspartic acid had reduced accumulation under drought conditions. Amino acids, such as branch chain alanine, valine, leucine also increased in samples of Triticeae species (IG132864, TR39477 and Bolal) under water-deficient conditions [108,109]. Urano et al. [110] also described the increased accretion of these branch chain amino acids in A. thaliana. Less and Galili [111] have suggested that activities of enzymes of amino acid catabolism were rapidly increased under drought stress.

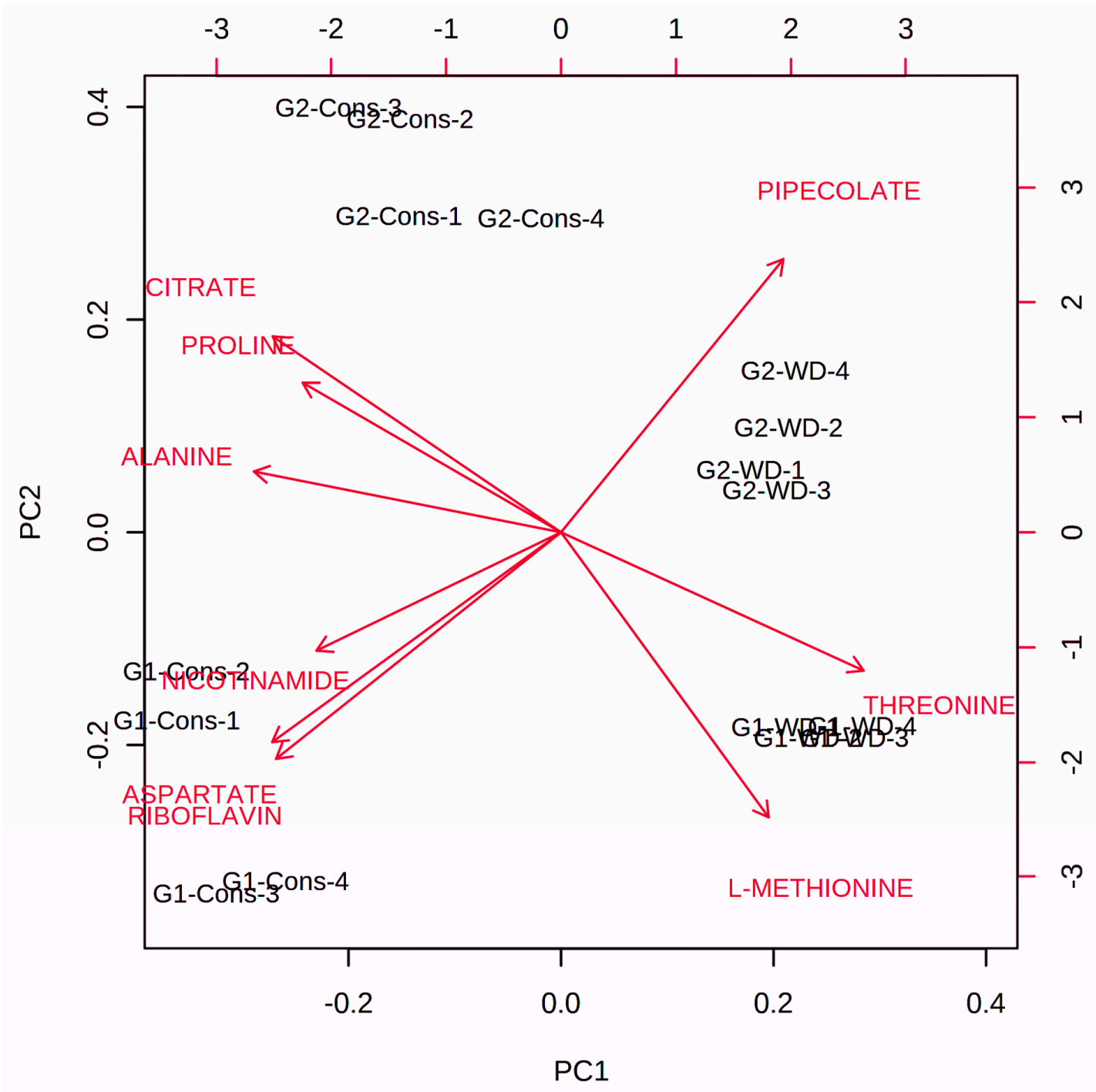

Figure 3. A principal component analysis (PCA) based biplot showing association among different metabolites induced by PGPR in chickpea leaves grown under consortium (Cons) and water deficit (WD) conditions. Samples with consortium and water deficit treatments did not overlap with each other showing that both the treatments have different levels of metabolites. G1-Drought Sensitive genotype; G2-Drought Tolerant genotype. 
On the other hand, sugar and its compounds such as fructose, mannitol, galactose, mannose and other non-reducing sugars and oligosaccharides provide a hydration shield around drought-sensitive proteins which can provide an initial defensive condition against further water depletion [112]. It has been reported previously that trehalose, glycinebetaine, carnitine, glutamate, proline, mannitol, polyols, fructans, sorbitol, oligosaccharides, and inorganic ions such as $\mathrm{K}^{+}$, sucrose, etc. are used as osmolytes to suppress cellularosmotic shock under water stress. The osmolyte accumulation prevents macromolecules by stabilizing the tertiary structure of proteins and by scavenging ROS $[113,114]$.

\subsection{Biofilm and Exopolysaccharides (EPS) Production by PGPR under Water Deficiency}

Biofilms are microbial communities in which differentiated cell populations are encapsulated by bacterial made extracellular matrices [115]. Most microorganisms are capable of forming biofilms in natural, clinical and industrial environments (Figure 4). Rhizobacteria are often found to form micro-colony or biofilm-like structures at the roots of plants [116,117]. Biofilms enhance soil accumulation, improve water status and enhance microbial biomass, thereby stimulating root exudates under pressure. Therefore, the production of a viscous extracellular matrix layer at the rhizosphere has a strong selectivity advantage, especially under stress conditions [118]. The matrix may also contribute to the mechanical stability of the biofilm and interact with other macromolecules and solutes of low molecular weight to provide several microenvironments within the biofilm [119-121].

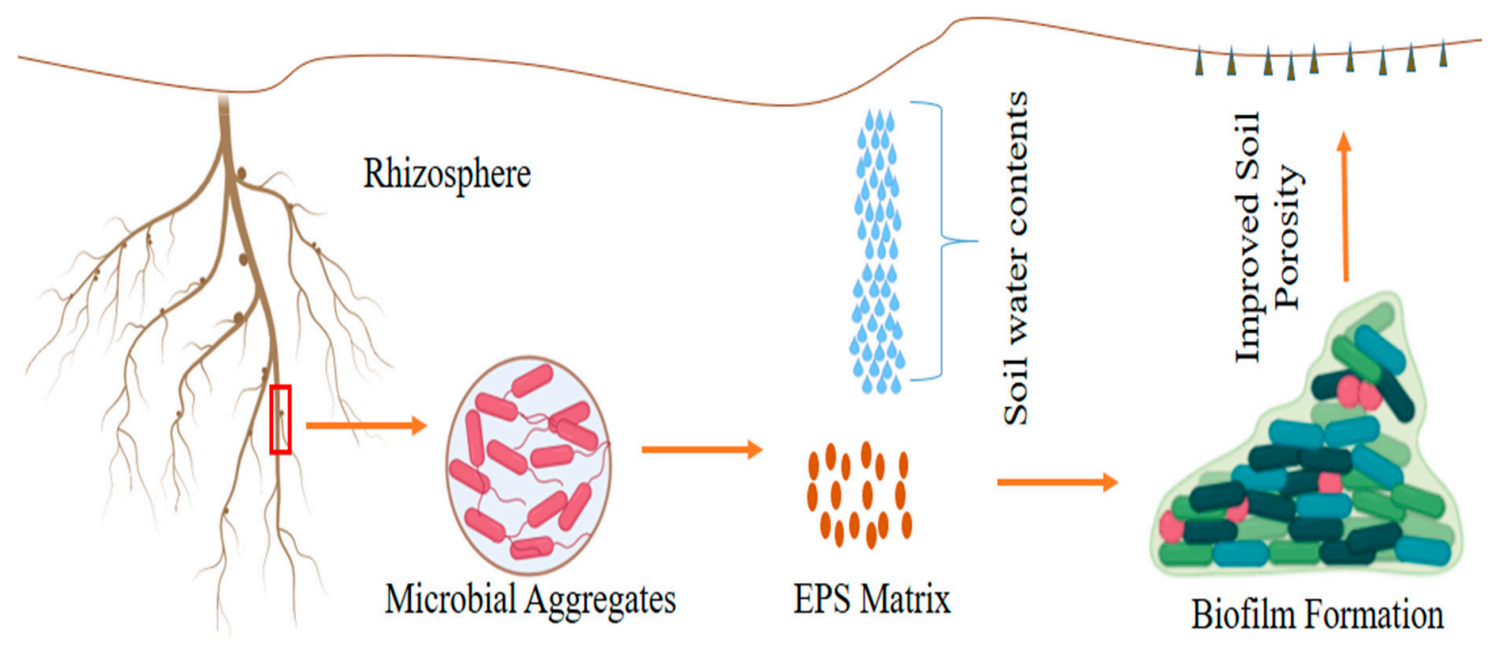

Figure 4. Microbial aggregates result in the formation of exopolysaccharides (EPS) and biofilm that provide protection to roots under abiotic stresses and improve the soil moisture content and soil porosity.

Studies have shown that the formation of PGPR biofilms has a pivotal role in defending plants under water deficient conditions. For example, P. polymyxa has been shown to colonize plant root tips, form biofilm-like structures and protect plants from water stress and pathogen infection [122]. As another example, a high mucus mutant of $P$. fluorescens $\mathrm{CHAO}$ strain indicating enhanced biofilm formation is believed to be beneficial for water budget and exhibits significantly enhanced carrot root colonization compared to its wild-type parent [123]. Khan et al. [124] reported that PGPR Planomicrobium chinense, Bacillus cereus and P. fluorescens alone or in combination resulted in biofilm formation in inoculated chickpea plants grown under sandy soil condition and protected the roots of plants from the adverse effects of unfavourable conditions. Besides this, B. subtilis strain ATCC 6051 is capable of forming biofilm-like structures on the roots of Arabidopsis plants and protecting Arabidopsis from high temperatures and infection with $P$. syringae [125-127].

Microbial EPS is essential for the production of biofilms and cell aggregates that help to protect cells from harsh conditions and may protect the substantial amount of heavy metals (Figure 4) [128]. Many studies demonstrated the importance of microbial EPS in water conservation under water-deficient conditions [129]. Furthermore, the bacterial EPS has also been found to 
be important in the bioremediation of wastes from water [130]. Exopolysaccharides produced by PGPR improved soil moisture content, plant biomass and leaf area of maize plant grown under stress condition [131]. Alami et al. [132] reported that the EPS-producing rhizobacteria control the aggregation of root-adhering soils. EPS-producing rhizobacteria will dramatically increase the number of soil macropores and soil aggregation in the rhizosphere, contributing to increased supply of water and fertilizer to inoculated plants [133-135]. EPS-producing rhizobacteria also bind cations such as $\mathrm{Na}^{+}$, with a rise in the population density of EPS-producing bacteria in the root zone expected to reduce the $\mathrm{Na}^{+}$amount available for plant absorption, thereby alleviating salt stress in plants grown in saline environments [136]. The EPS-producing bacterial population responded to adverse environmental conditions by contributing to soil aggregation and increased the retention of water in the root rhizosphere under water stress conditions [137]. The efficacy of inoculation with rhizobacteria, P. mendocina, has been documented for both soil stabilization and soil fertility enhancement under non-saline conditions [138]. The function of alginates in bacterial adhesion and biofilm formation for Pseudomonas aeruginosa has been examined in depth. It has been shown that alginate increases the binding and anchoring of P. aeruginosa strains on many surfaces and is the key constituent in the biofilm matrix $[139,140]$.

\subsection{1-Aminocyclopropane-1-Carboxylic Acid (ACC) Deaminase Activity of PGPR to Combat Water Deficit Stress}

One of the key pathways used by PGPR to promote water conservation by plant growth and development during a water shortage is the reduction of ethylene levels by 1-aminocyclopropane-1-carboxylic acid (ACC), the immediate precursor of ethylene in plants (Figure 2) [141]. The enzyme hydrolyzes ACC to $\alpha$-ketobutyrate and ammonia [142]. Plants that are inoculated with PGPR containing ACC deaminase have been found to be substantially more resistant to the deleterious effects of stress ethylene that is synthesized as a result of adverse environments such as heavy metals toxicity [143], presence of phytopathogens [144], hypoxia [145], high salinity and drought stress [146]. It has been stated in most of these cases that the PGPR containing ACC deaminase significantly decreases the ACC activity in the stressed plants, thus reducing the level of ethylene biosynthesis and consequently protecting the plants from their deleterious effects. The usage of plant growth-promoting bacteria containing ACC deaminase is helpful to facilitate plant growth and water conservation in water-deficient conditions [147].

The impact of inoculation with ACC deaminase-containing rhizobacteria on water use efficiency was clearly evident in crop plants. Pseudomonas fluorescens biotype G (ACC-5) was found to be more promising at low humidity ( $25 \%$ field capacity), because of its maximum water use efficiency compared to the respective uninoculated controls. Similarly, inoculation was shown to be efficient in increasing the productivity of water usage when measured on a dry weight basis [148]. The inoculation of ACC deaminase PGPR Achromobacter piechaudii ARV8 with pepper and tomato seedling exposed to transient water stress significantly increased the fresh and dry weights of the plants [149]. Recently, beneficial effects of ACC deaminase-producing bacterium Variovorax sp. in improving the nodulation and growth of spiny brooms grown in arid regions of Tunisia have been observed [150]. Likewise, ACC deaminase-containing Variovorax paradoxus has also caused physiological modifications in Pisum sativum L. grown under moisture deficient condition [151]. Positive effects of ACC deaminase bacteria on shoots and roots biomass, transpiration rate and leaf area of plants were also observed in short-term experiments (Table 1). In long-term studies, plants inoculated with ACC deaminase bacteria provided more seed yield (25-41\%), number of seeds, and accumulation of seed nitrogen than uninoculated plants, and helped preserve water status [152]. 
Table 1. Impacts of 1-aminocyclopropane-1-carboxylic acid (ACC) deaminase-producing bacteria on plant growth and drought stress tolerance.

\begin{tabular}{|c|c|c|c|}
\hline ACC Producing PGPR & Host Plants & Results & References \\
\hline A. piechaudii ARV8 & Solanum lycopersicum L. & $\begin{array}{l}\text { Enhanced plant biomass and decrease } \\
\text { in ethylene levels. }\end{array}$ & [153] \\
\hline A. piechaudii ARV8 & Pisum sativum L. & $\begin{array}{l}\text { Improve root-shoot ratio under low } \\
\text { soil moisture content. }\end{array}$ & [154] \\
\hline Pseudomonas sp. & Pisum sativum L. & $\begin{array}{l}\text { Improve the plant growth and yield } \\
\text { and reduce the triple response } \\
\text { of ethylene. }\end{array}$ & [155] \\
\hline P. fluorescens & Pisum sativum L. & $\begin{array}{l}\text { Positive impacts on plant growth } \\
\text { under severe drought stress. }\end{array}$ & [156] \\
\hline V. paradoxus 5C-2 & Pisum sativum L. & $\begin{array}{l}\text { Induce the abscisic acid (ABA) } \\
\text { signalling in plants and Improve the } \\
\text { soil nutrient content. }\end{array}$ & [157] \\
\hline $\begin{array}{l}\text { Rhizosphere bacteria } \\
\text { containing } \\
\text { ACC-deaminase }\end{array}$ & Triticum aestivum & $\begin{array}{l}\text { Enhance root-shoot length and } \\
\text { improve the water and } \\
\text { nutrient uptakes. }\end{array}$ & [158] \\
\hline $\begin{array}{l}\text { Bacillus 23-B + } \\
\text { Pseudomonas sp. 6-P + } \\
\text { Mesorhizobium ciceri }\end{array}$ & & $\begin{array}{l}\text { Improve seed germination and root } \\
\text { length in chickpea under } \\
\text { moisture stress. }\end{array}$ & [159] \\
\hline Bacillus licheniformis K11 & Pepper nigrum & $\begin{array}{l}\text { Enhance the expression of stress } \\
\text { related genes e.g., Cadh, VA, sHSP, } \\
\text { and CaPR-10. }\end{array}$ & [160] \\
\hline Citricoccus zhacoinesis B-4 & Allium сера & $\begin{array}{l}\text { Promote plant growth and } \\
\text { germination index. }\end{array}$ & [161] \\
\hline $\begin{array}{c}\text { Ochrobactrum } \\
\text { pseudogrignonense RJ12, } \\
\text { Pseudomonas sp. RJ15 } \\
\text { and B. subtilis RJ46 }\end{array}$ & $\begin{array}{l}\text { Vigna mungo L. } \\
\text { Pisum satioum L. }\end{array}$ & $\begin{array}{l}\text { Show positive impacts on seed } \\
\text { germination, improve root and shoot } \\
\text { length and regulate ethylene level. }\end{array}$ & [162] \\
\hline
\end{tabular}

\section{Development of Root System by PGPR}

Rhizobium helps plants in maintaining a favourable water status in their tissues under water-deficient conditions by enhancing root development (Figure 1). Rhizosphere bacteria that promote plant growth colonize roots and maintain symbiotic interactions to promote plant growth and provide protections against stresses [163]. Different strains of PGPRs are well known for their positive impact on plant growth and also helping in water stress such as Azospirillum sp., Azotobacter sp., and $P$. fluorescens [164]. Root biomass was large in plants inoculated with Phyllobacterium brassicacearum STM196, and also increased the water absorption by changing root architecture. Studies conducted under reproductive conditions have shown that STM196 increases lateral root length [165], as well as the density and length of root hairs [166]. STM196 resulted in a greater contact surface with the soil causing higher water flow from roots to the shoot. Some rhizosphere bacteria help plants in maintaining a desirable moisture level in their tissues under water-deficient conditions by improving the root development [167]. Inoculation with PGPR strains improved plant growth by strengthening the root architecture, consequently increasing nutrient uptake $[168,169]$.

Some PGPRs like A. brasilense, B. japonicum, B. cereus, Paenibacillus illinoisensis, P. fluorescens promote root development and alter root structure by producing plant hormones such as IAA, resulting in increased root surface area and increased number of root tips [170]. This root stimulation can help plants fight pathogens. It has also been suggested that PGPR increases plant uptake of water and mineral ions by proton pump ATPase stimulation, despite the lack of experimental evidence [171]. 


\section{Improving Nutrient Availability and Maintenance of Soil Quality}

Drought stress affects soil biological, physical and chemical activities. It not only decreases plant nutrient supply but also has harmful impacts on plant and soil health due to a rise in soil temperature [172]. Under drought conditions, the nutrient availability to the plant is seriously impaired; however, the usage of appropriate microorganisms restores nutrient bioavailability in drought-stressed conditions. Several PGPR have been isolated in recent decades and have been suggested for use in sustainable agriculture under water deficit conditions [173]. Plant growth-promoting bacteria found to be very effective in substantially increasing soil nutrients content thus improving crop yields [174]. PGPRs of the genera Arthrobacter, Azotobacter, Azospirillum, Bacillus, Enterobacter, Pseudomonas, Serratia and Streptomyces were largely documented for this purpose [175]. PGPR may have a beneficial impact on plant growth and development, possibly because of a nutrient mobilization in the soil, nitrogen fixation and excretion of different plant hormones (Figure 2). Using PGPR may help in reducing the use of chemical fertilizers or increase the nutrient-use efficiencies, particularly for low-mobility nutrients such as iron and phosphorus [176,177]. In particular, iron forms insoluble hydroxides in high $\mathrm{pH}$ soils, and supply of bioavailable Fe to plants is reduced. It was previously reported that the production of siderophores by genus Pseudomonas enhanced the solubility of Fe and contributed to the overall iron requirements of plants, especially in calcareous soils [178].

Soil quality is critical for the improvement of sustainable farming under extreme drought conditions. It encourages penetration of water, provides optimal habitat for soil organisms and an optimal aeration to roots and soil organisms, and helps in preventing soil erosion [179]. Microorganisms have been observed to have a direct impact on soil properties and quality, since they may associate with other microorganisms in the rhizosphere (Figure 4) [180-182]. Soil microorganisms play an important role in controlling the processes of decomposition of organic matter, and the supply of plant nutrients, such as N, P and K. Microbial inoculants are well known as an essential component of advanced nutrient management contributing to sustainable agriculture [183]. In addition, microbial inoculants can be used to improve crop production as an economic input; fertilizer doses can be reduced, and nutrient use efficiencies can be increased [184].

\section{Changes in Plant Functional Traits}

It is well established that extreme deficient water stress affects plant growth, water status, and is responsible for a decrease in photosynthetic ability, especially through stomatal closure and leaf senescence. Non-destructive experiments based on chlorophyll fluorescence imaging were commonly used to decipher the effect of different water potentials on plant physiology, but only rarely used at high performance [185]. Measurements of chlorophyll fluorescence were performed at high throughput to unravel the influence of rhizobacteria on the responses of plants to drought (Figure 5). There are numerous photosynthetic parameters that exist; dark-adapted Fv/Fm represents the optimal efficiency of photosystem II (PSII) and is thus one of the most commonly used parameters for analyzing the physiological modulations in leaf. Most commonly, the mean Fv/Fm of the photosynthetic organ or the whole plant is used to describe the stressor response [186]. The major decrease in mean Fv/Fm during a prolonged water deficit is commonly correlated with high leaf senescence. With a higher proportion of leaf senescence, STM196-inoculated plants may persist and thus provide higher resistance to photosynthetic damage from the leaves [187-189].

Inoculated plants thus demonstrated reduced mortality rate after the establishment of water tension. Leaf senescence reflects a common way to conserve resources. It allows translocation to reproductive organs and decreases water intake of older and less-productive leaves [190]. Therefore, leaf senescence is an adaptive trait which will help plant survival under stressful conditions. The increase in chlorophyll content may contribute to the improvement in plant photosynthetic efficiency triggered by PGPR. Rice plants inoculated with arbuscular mycorrhizal fungus under water tension showed a positive association between water budget and PSII efficiency [191]. In A. thaliana, the inoculation of the Burkholderia phytofirmans PsJn strain enhances the senescent leave at flowering under well-watered 
environments. It is widely confirmed that rhizobacteria increase the content of leaf water which results in increased plant resistance under drought stress [192-194].

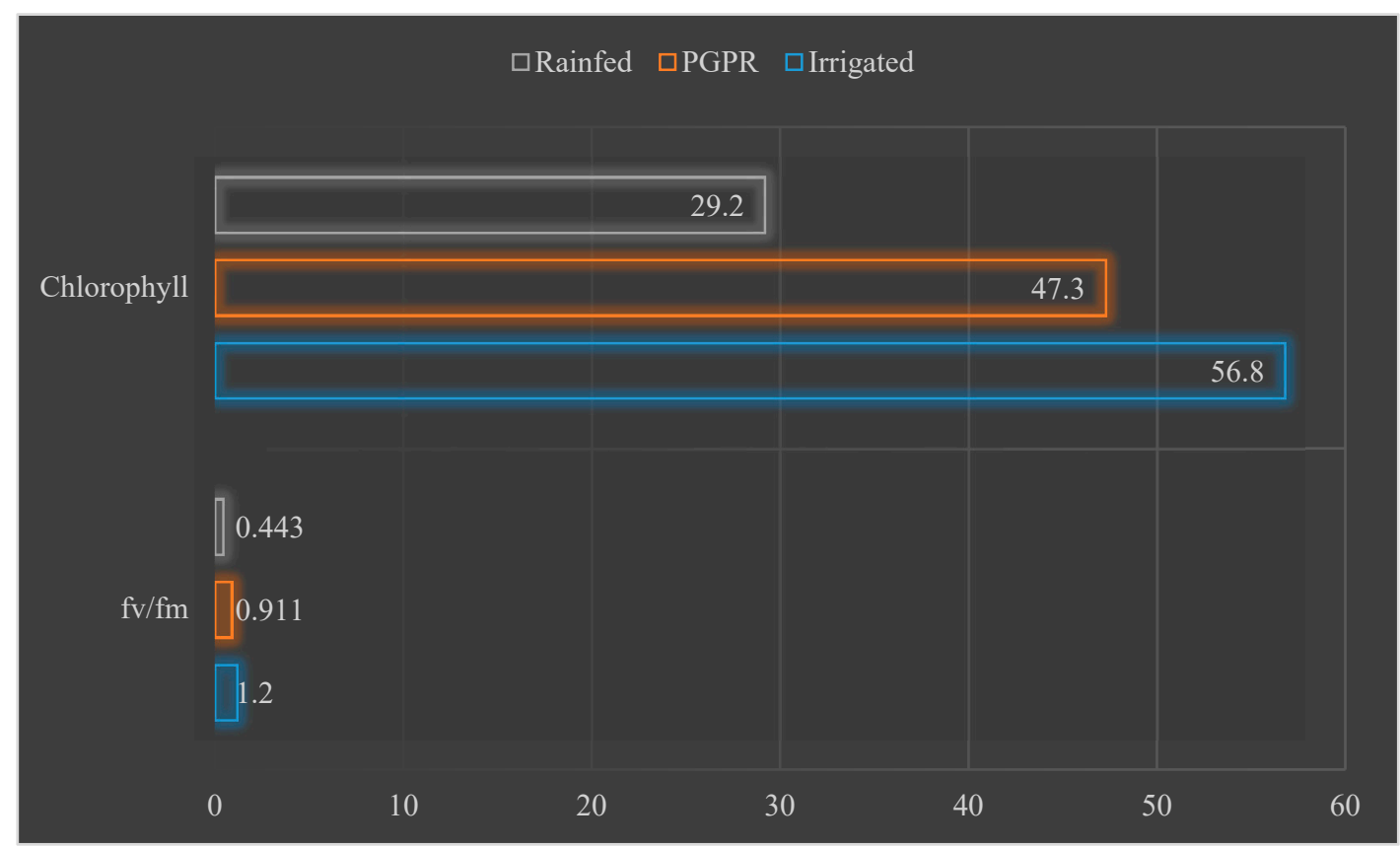

Figure 5. Effects of PGPR on leaf chlorophyll content and photochemical efficiency of chickpea plants grown under moisture stress conditions.

\section{Molecular Mechanisms to Mitigate Drought Stress Induced by PGPR}

Plant responses to environmental stresses are complex mechanisms which involve modulation in the expression of stress-related genes $[195,196]$. These genes support stress management by inducing two different types of protein, either functional proteins that act directly, such as mRNA binding proteins, chaperones, LEA proteins, and osmotic regulators, or regulatory proteins that regulate transcription and signalling pathways [197]. Plants recognise abiotic stresses by specific receptors in the cell walls or intracellularly, which involve various sensing system. ABA plays a significant role in abiotic stress responses by influences in the expression of various genes to mediate systemic stress tolerance [198-200]. Additionally, a variety of compounds serve as systemic signals to alleviate stress within the plants, for example, small RNAs (sRNA), peptides and metabolites [198].

Stress tolerance can be enhanced by treating plants with several PGPR stains which up-regulate stress tolerance inducing genes. The rice plants treated with $P$. fluoresces induced multiples differential gene expression, for example, ERD15 (Early response to dehydration15), COC1, Hsp20 and bZIP1 (chaperones in ABA signalling pathway), PKDP (protein kinase), and COX1 (regulate energy and carbohydrate metabolism). Arabidopsis thaliana treated with Pseudomonas strains promote the expression of ACO, ACS (ethylene biosynthesis), ADC, CPA, AIH, SPMS, SPDS and SAMDC (polyamine biosynthesis), VSP1 (ethylene-responsive gene), Pdf1.2 (JA marker genes) and PR1 (SA regulated gene). Similarly in Lycium barium it increased the expression of LbKT1, LbSKOR (encoding potassium channels) and RAB18 (ABA-responsive gene) in drought conditions [201-203]. Pepper plant inoculated with Bacillus sp. enhanced 1.5 fold increased the expression of sHSP (small heat-shock proteins), VA, and Cadhn. Under drought conditions, the inoculation of A. brasilense NO40 and Bacillus amyloliquefaciens 5113 alleviates the deleterious effects in the leaves of wheat plants by upregulation of APX1, HSP17.8 and SAMS1 stress-responsive genes [204]. This overexpression of genes increased the ascorbate-glutathione redox cycle, which helps to overcome the adverse effect of water stress.

Recent approaches to system biology and omics analysis of transcripts, proteins and metabolites have improved our knowledge of molecular responses in stressed plants and plant-microbe 
interactions [205,206]. PGPR-induced physiological and metabolic alternation is anticipated to be driven by molecular alteration that has culminated in protein and post-translation modifications. The combination of proteomics and metabolomics profiling for stressed, non-stressed and PGPR-treated plants will also help to classify metabolic and molecular modulations involved under stress conditions in beneficial plant-microbe interactions and help to elucidate the essence of the defence. Under drought stress, the proteomic and metabolic studies and PGPR responses have been reported in many plants $[207,208]$. However, the impact of beneficial microbes on gene expression and metabolite aggregation in PGPR-treated crop plants remains poorly investigated.

\section{Conclusions and Future Perspectives}

Many plant-associated bacteria are well known for their ability to promote plant growth and improve water-use efficiency and tolerance to various abiotic stresses. These PGPR species improve the water conservation status in many plants and are capable of overproducing biofilms, exopolysaccharides and trehalose, in their cells and improve the root system and soil fertility status. They help plants to improve their root system and maintain its proper cellular moisture status, resultantly improving plant survival under severe water-deficient conditions. Phytohormones are an important component of plant growth and development under drought stress. The PGPR inoculation changes the levels of plant hormones and other metabolites which help in plant adaptations through their response to the plant water balance, nutrient uptake and translocation, gas exchange, and the movement of photosynthates between tissues. In addition, polyamines are also found to be highly associated in enhancing the water balances and promote the growth of the plants.

In future research, studies can be focused on how PGPR can alter metabolic profiling in plants under water deficiency and on examining further the gene expression or protein changes that are directly involved in the production of these metabolites. It is also important to unravel the complex genetic network and metabolic-interacting events which mediate the host-microbe interactions.

Author Contributions: Conceived of the presented idea, N.K.; developed the theory and performed the computations, N.K. and S.A.; writing-original draft preparation, N.K., S.A., A.M., M.A.S. writing-review and editing, N.K., S.A., H.T., S.L., H.Y. and S.A.; supervision, N.K.; verified the numerical results, N.K., S.A., H.T., S.L., M.A.S., H.Y. and A.M. All authors have read and agreed to the published version of the manuscript.

Funding: This research received no external funding.

Conflicts of Interest: The authors declare no conflict of interest.

\section{References}

1. Campbell, A. The use of wild food plants, and drought in Botswana. J. Arid. Environ. 1986, 11, 81-91. [CrossRef]

2. Christensen, J.H.; Christensen, O.B. A summary of the PRUDENCE model projections of changes in European climate by the end of this century. Clim. Chang. 2007, 81, 7-30. [CrossRef]

3. Hsiao, T.C.; $\mathrm{Xu}$, L. Sensitivity of growth of roots versus leaves to water stress: Biophysical analysis and relation to water transport. J. Exp. Bot. 2000, 51, 1595-1616. [CrossRef] [PubMed]

4. Vessey, J.K. Plant growth promoting rhizobacteria as biofertilizers. Plant Soil 2003, 255, 571-586. [CrossRef]

5. Zhao, J.; Ren, W.; Zhi, D.; Wang, L.; Xia, G. Arabidopsis DREB1A/CBF3 bestowed transgenic tall fescue increased tolerance to drought stress. Plant Cell Rep. 2007, 26, 1521-1528. [CrossRef]

6. Rampino, P.; Pataleo, S.; Gerardi, C.; Mita, G.; Perrotta, C. Drought stress response in wheat: Physiological and molecular analysis of resistant and sensitive genotypes. Plant Cell Environ. 2006, 29, 2143-2152. [CrossRef]

7. Khan, N.; Bano, A. Effects of exogenously applied salicylic acid and putrescine alone and in combination with rhizobacteria on the phytoremediation of heavy metals and chickpea growth in sandy soil. Int. J. Phytoremediat. 2018, 16, 405-414. [CrossRef] [PubMed]

8. Lafitte, H.R.; Yongsheng, G.; Yan, S.; Li, Z.-K. Whole plant responses, key processes, and adaptation to drought stress: The case of rice. J. Exp. Bot. 2006, 58, 169-175. [CrossRef]

9. Kamara, A.Y.; Ekeleme, F.; Chikoye, D.; Omoigui, L.O. Planting Date and Cultivar Effects on Grain Yield in Dryland Corn Production. Agron. J. 2009, 101, 91-98. [CrossRef] 
10. Atouei, M.T.; Pourbabaee, A.A.; Shorafa, M. Alleviation of Salinity Stress on Some Growth Parameters of Wheat by Exopolysaccharide-Producing Bacteria. Iran. J. Sci. Technol. Trans. A Sci. 2019, 43, 2725-2733. [CrossRef]

11. Dimkpa, C.; Merten, D.; Svatoš, A.; Büchel, G.; Kothe, E. Siderophores mediate reduced and increased uptake of cadmium byStreptomyces tendaeF4 and sunflower (Helianthus annuus), respectively. J. Appl. Microbiol. 2009, 107, 1687-1696. [CrossRef]

12. Farooq, M.; Hussain, M.; Siddique, K.H.M. Drought Stress in Wheat during Flowering and Grain-filling Periods. Crit. Rev. Plant Sci. 2014, 33, 331-349. [CrossRef]

13. Nair, P.R. Agroecosystem management in the 21st century: It is time for a paradigm shift. J. Trop. Agric. 2008, $46,1-12$.

14. Guo, P.; Baum, M.; Grando, S.; Ceccarelli, S.; Bai, G.; Li, R.; Von Korff, M.; Varshney, R.K.; Graner, A.; Valkoun, J. Differentially expressed genes between drought-tolerant and drought-sensitive barley genotypes in response to drought stress during the reproductive stage. J. Exp. Bot. 2009, 60, 3531-3544. [CrossRef]

15. Venuprasad, R.; Lafitte, H.R.; Atlin, G.N. Response to Direct Selection for Grain Yield under Drought Stress in Rice. Crop. Sci. 2007, 47, 285-293. [CrossRef]

16. Gaffney, J.; Schussler, J.; Löffler, C.; Cai, W.; Paszkiewicz, S.; Messina, C.D.; Groeteke, J.; Keaschall, J.; Cooper, M. Industry-Scale Evaluation of Maize Hybrids Selected for Increased Yield in Drought-Stress Conditions of the US Corn Belt. Crop. Sci. 2015, 55, 1608-1618. [CrossRef]

17. Akram, R.; Natasha; Fahad, S.; Hashmi, M.Z.; Wahid, A.; Adnan, M.; Mubeen, M.; Khan, N.; Rehmani, M.I.A.; Awais, M.; et al. Trends of electronic waste pollution and its impact on the global environment and ecosystem. Environ. Sci. Pollut. Res. 2019, 26, 16923-16938. [CrossRef]

18. Denef, K.; Roobroeck, D.; Wadu, M.C.M.; Lootens, P.; Boeckx, P. Microbial community composition and rhizodeposit-carbon assimilation in differently managed temperate grassland soils. Soil. Biol. Biochem. 2009, 41, 144-153. [CrossRef]

19. Nasim, W.; Amin, A.; Fahad, S.; Awais, M.; Khan, N.; Mubeen, M.; Wahid, A.; Rehman, M.H.; Ihsan, M.Z.; Ahmad, S.; et al. Future risk assessment by estimating historical heat wave trends with projected heat accumulation using SimCLIM climate model in Pakistan. Atmos. Res. 2018, 205, 118-133. [CrossRef]

20. Ngumbi, E.; Kloepper, J. Bacterial-mediated drought tolerance: Current and future prospects. Appl. Soil Ecol. 2016, 105, 109-125. [CrossRef]

21. Gontia-Mishra, I.; Sapre, S.; Sharma, A.; Tiwari, S. Amelioration of drought tolerance in wheat by the interaction of plant growth-promoting rhizobacteria. Plant Biol. 2016, 18, 992-1000. [CrossRef]

22. Yasmin, F.; Othman, R.; Sijam, K.; Saad, M.S. Effect of PGPR inoculation on growth and yield of sweetpotato. J. Biol. Sci. 2007, 7, 421-424.

23. Bresson, J.; Varoquaux, F.; Bontpart, T.; Touraine, B.; Vile, D. The PGPR strain P hyllobacterium brassicacearum STM 196 induces a reproductive delay and physiological changes that result in improved drought tolerance in A rabidopsis. New Phytol. 2013, 200, 558-569. [CrossRef]

24. Barnawal, D.; Singh, R.; Singh, R.P. Role of Plant Growth Promoting Rhizobacteria in Drought Tolerance. In PGPR Amelioration in Sustainable Agriculture; Elsevier BV: Amsterdam, The Netherlands, 2019; pp. 107-128.

25. Yadav, S.K. Cold stress tolerance mechanisms in plants. A review. Agron. Sustain. Dev. 2010, 30, 515-527. [CrossRef]

26. Kaushal, M.; Wani, S.P. Plant-growth-promoting rhizobacteria: Drought stress alleviators to ameliorate crop production in drylands. Ann. Microbiol. 2015, 66, 35-42. [CrossRef]

27. Wang, C.; Guo, Y.; Wang, C.; Liu, H.; Niu, D.; Wang, Y.; Guo, J. Enhancement of tomato (Lycopersicon esculentum) tolerance to drought stress by plant-growth-promoting rhizobacterium (PGPR) Bacillus cereus AR156. J. Agric. Biotechnol. 2012, 20, 1097-1105.

28. Barnawal, D.; Bharti, N.; Pandey, S.S.; Pandey, A.; Chanotiya, C.S.; Kalra, A. Plant growth-promoting rhizobacteria enhance wheat salt and drought stress tolerance by altering endogenous phytohormone levels and TaCTR1/TaDREB2 expression. Physiol. Plant. 2017, 161, 502-514. [CrossRef]

29. Liu, F.; Xing, S.; Ma, H.; Du, Z.; Ma, B. Cytokinin-producing, plant growth-promoting rhizobacteria that confer resistance to drought stress in Platycladus orientalis container seedlings. Appl. Microbiol. Biotechnol. 2013, 97, 9155-9164. [CrossRef]

30. Vaishnav, A.; Choudhary, D.K. Regulation of Drought-Responsive Gene Expression in Glycine max L. Merrill is Mediated Through Pseudomonas simiae Strain AU. J. Plant Growth Regul. 2018, 38, 333-342. [CrossRef] 
31. Ansari, F.A.; Ahmad, I. Alleviating Drought Stress of Crops through PGPR: Mechanism and Application. In Microbial Interventions in Agriculture and Environment; Springer Science and Business Media LLC: Berlin/Heidelberg, Germany, 2019; pp. 341-358.

32. Zheng, W.; Zeng, S.; Bais, H.; Lamanna, J.M.; Hussey, D.S.; Jacobson, D.L.; Jin, Y. Plant Growth-Promoting Rhizobacteria (PGPR) Reduce Evaporation and Increase Soil Water Retention. Water Resour. Res. 2018, 54, 3673-3687. [CrossRef]

33. Kumar, A.; Patel, J.S.; Meena, V.S.; Srivastava, R. Recent advances of PGPR based approaches for stress tolerance in plants for sustainable agriculture. Biocatal. Agric. Biotechnol. 2019, 20, 101271. [CrossRef]

34. Armada, E.; Roldán, A.; Azcon, R. Differential Activity of Autochthonous Bacteria in Controlling Drought Stress in Native Lavandula and Salvia Plants Species Under Drought Conditions in Natural Arid Soil. Microb. Ecol. 2013, 67, 410-420. [CrossRef]

35. Venkateswarlu, B.; Shanker, A.K. Climate change and agriculture: Adaptation and mitigation stategies. Indian J. Agron. 2009, 54, 226-230.

36. Niu, X.; Song, L.; Xiao, Y.; Ge, W. Drought-Tolerant Plant Growth-Promoting Rhizobacteria Associated with Foxtail Millet in a Semi-arid Agroecosystem and Their Potential in Alleviating Drought Stress. Front. Microbiol. 2018, 8, 2580. [CrossRef]

37. Augé, R.M. Water relations, drought and vesicular-arbuscular mycorrhizal symbiosis. Mycorrhiza 2001, 11, 3-42. [CrossRef]

38. Piccoli, P.; Bottini, R. Abiotic Stress Tolerance Induced by Endophytic PGPR. In Soil Biology; Springer Science and Business Media LLC: Berlin/Heidelberg, Germany, 2013; pp. 151-163.

39. Panda, R.; Das, M.; Nayak, S. Estimation and optimization of exopolysaccharide production from rice rhizospheric soil and its interaction with soil carbon pools. Rhizosphere 2020, 14, 100206. [CrossRef]

40. Calvo-Polanco, M.; Sánchez-Romera, B.; Aroca, R.; Asins, M.J.; Declerck, S.; Dodd, I.C.; Martinez-Andujar, C.; Albacete, A.; Ruiz-Lozano, J.M. Exploring the use of recombinant inbred lines in combination with beneficial microbial inoculants (AM fungus and PGPR) to improve drought stress tolerance in tomato. Environ. Exp. Bot. 2016, 131, 47-57. [CrossRef]

41. Naseem, H.; Ahsan, M.; Shahid, M.A.; Khan, N. Exopolysaccharides producing rhizobacteria and their role in plant growth and drought tolerance. J. Basic Microbiol. 2018, 58, 1009-1022. [CrossRef]

42. Joshi, R.; Wani, S.H.; Singh, B.; Bohra, A.; Dar, Z.A.; Lone, A.A.; Pareek, A.; Singla-Pareek, S.L. Transcription Factors and Plants Response to Drought Stress: Current Understanding and Future Directions. Front. Plant Sci. 2016, 7, 1029. [CrossRef]

43. Jaleel, C.A.; Manivannan, P.A.R.A.M.A.S.I.V.A.M.; Wahid, A.; Farooq, M.; Al-Juburi, H.J.; Somasundaram, R.A.M.A.M.U.R.T.H.Y.; Panneerselvam, R. Drought stress in plants: A review on morphological characteristics and pigments composition. Int. J. Agric. Biol. 2009, 11, 100-105.

44. Lucy, M. Management Strategies for Balance Herbicide in Chickpeas; GRDC: Canberra, Australia, 2004.

45. Zhao, P.; Liu, P.; Shao, J.; Li, C.; Wang, B.; Guo, X.; Yan, B.; Xia, Y.; Peng, M. Analysis of different strategies adapted by two cassava cultivars in response to drought stress: Ensuring survival or continuing growth. $J$. Exp. Bot. 2014, 66, 1477-1488. [CrossRef] [PubMed]

46. Pallai, R.; Hynes, R.K.; Verma, B.; Nelson, L.M. Phytohormone production and colonization of canola (Brassica napusL.) roots byPseudomonas fluorescens6-8 under gnotobiotic conditions. Can. J. Microbiol. 2012, 58, 170-178. [CrossRef] [PubMed]

47. Kasim, W.A.; Osman, M.E.; Omar, M.N.; El-Daim, I.A.A.; Bejai, S.; Meijer, J. Control of Drought Stress in Wheat Using Plant-Growth-Promoting Bacteria. J. Plant Growth Regul. 2012, 32, 122-130. [CrossRef]

48. Todaka, D.; Shinozaki, K.; Yamaguchi-Shinozaki, K. Recent advances in the dissection of drought-stress regulatory networks and strategies for development of drought-tolerant transgenic rice plants. Front. Plant Sci. 2015, 6, 84. [CrossRef]

49. Szota, C.; Farrell, C.; Williams, N.S.G.; Arndt, S.K.; Fletcher, T.D. Drought-avoiding plants with low water use can achieve high rainfall retention without jeopardising survival on green roofs. Sci. Total. Environ. 2017, 603, 340-351. [CrossRef] [PubMed]

50. Dos Reis, S.P.; Marques, D.N.; Lima, A.M.; De Souza, C.R.B. Plant Molecular Adaptations and Strategies Under Drought Stress. In Drought Stress Tolerance in Plants; Springer Science and Business Media LLC: Berlin/Heidelberg, Germany, 2016; Volume 2, pp. 91-122. 
51. García, J.E.; Maroniche, G.; Creus, C.; Suarez-Rodríguez, R.; Ramirez-Trujillo, J.A.; Groppa, M.D. In vitro PGPR properties and osmotic tolerance of different Azospirillum native strains and their effects on growth of maize under drought stress. Microbiol. Res. 2017, 202, 21-29. [CrossRef]

52. Schellenbaum, L.; Muller, J.; Boller, T.; Wiemken, A.; Schuepp, H. Effects of drought on non-mycorrhizal and mycorrhizal maize: Changes in the pools of non-structural carbohydrates, in the activities of invertase and trehalase, and in the pools of amino acids and imino acids. New Phytol. 1998, 138, 59-66. [CrossRef]

53. Khan, N.; Bano, A. Rhizobacteria and Abiotic Stress Management. In Plant Growth Promoting Rhizobacteria for Sustainable Stress Management; Springer: Singapore, 2019; pp. 65-80.

54. Ikram, M.; Ali, N.; Guljan, F.; Khan, N. Endophytic fungal diversity and their interaction with plants for agriculture sustainability under stressful condition. Recent Pat. Food Nutr. Agric. 2019, 10, 1. [CrossRef]

55. Shulaev, V. Metabolomics technology and bioinformatics. Brief. Bioinform. 2006, 7, 128-139. [CrossRef]

56. Uppalapati, S.R.; Ishiga, Y.; Doraiswamy, V.; Bedair, M.; Mittal, S.; Chen, J.; Chen, R. Loss of abaxial leaf epicuticular wax in Medicago truncatula irg1/palm1 mutants results in reduced spore differentiation of anthracnose and nonhost rust pathogens. Plant Cell 2012, 24, 353-370. [CrossRef]

57. Lamizadeh, E.; Enayatizamir, N.; Motamedi, H. Isolation and Identification of Plant Growth-Promoting Rhizobacteria (PGPR) from the Rhizosphere of Sugarcane in Saline and Non-Saline Soil. Int. J. Curr. Microbiol. Appl. Sci. 2016, 5, 1072-1083. [CrossRef]

58. Pagnani, G.; Galieni, A.; Stagnari, F.; Pellegrini, M.; Del Gallo, M.; Pisante, M. Open field inoculation with PGPR as a strategy to manage fertilization of ancient Triticum genotypes. Biol. Fertil. Soils 2019, 56, 1-14. [CrossRef]

59. Rezaei-Chiyaneh, E.; Amirnia, R.; Machiani, M.A.; Javanmard, A.; Maggi, F.; Morshedloo, M.R. Intercropping fennel (Foeniculum vulgare L.) with common bean (Phaseolus vulgaris L.) as affected by PGPR inoculation: A strategy for improving yield, essential oil and fatty acid composition. Sci. Hortic. 2020, 261, 108951. [CrossRef]

60. Rubin, R.L.; Van Groenigen, K.J.; Hungate, B.A. Plant growth promoting rhizobacteria are more effective under drought: A meta-analysis. Plant Soil 2017, 416, 309-323. [CrossRef]

61. Kohler, J.; Hernández, J.-A.; Caravaca, F.; Roldán, A. Plant-growth-promoting rhizobacteria and arbuscular mycorrhizal fungi modify alleviation biochemical mechanisms in water-stressed plants. Funct. Plant Biol. 2008, 35, 141-151. [CrossRef]

62. Odoh, C.K. Plant Growth Promoting Rhizobacteria (PGPR): A Bioprotectant bioinoculant for Sustainable Agrobiology. A Review. Int. J. Adv. Res. Biol. Sci. 2017, 4, 123-142. [CrossRef]

63. Swamy, M.K.; Akhtar, M.S.; Sinniah, U.R. Response of PGPR and AM Fungi Toward Growth and Secondary Metabolite Production in Medicinal and Aromatic Plants. In Plant, Soil and Microbes; Springer Science and Business Media LLC: Berlin/Heidelberg, Germany, 2016; pp. 145-168.

64. Rouphael, Y.; Franken, P.; Schneider, C.; Schwarz, D.; Giovannetti, M.; Agnolucci, M.; De Pascale, S.; Bonini, P.; Colla, G. Arbuscular mycorrhizal fungi act as biostimulants in horticultural crops. Sci. Hortic. 2015, 196, 91-108. [CrossRef]

65. Kenneth, O.C.; Nwadibe, E.C.; Kalu, A.U.; Unah, U.V. Plant Growth Promoting Rhizobacteria (PGPR): A Novel Agent for Sustainable Food Production. Am. J. Agric. Biol. Sci. 2019, 14, 35-54. [CrossRef]

66. Prasad, M.; Srinivasan, R.; Chaudhary, M.; Choudhary, M.; Jat, L.K. Plant Growth Promoting Rhizobacteria (PGPR) for Sustainable Agriculture. In PGPR Amelioration in Sustainable Agriculture; Elsevier BV: Amsterdam, The Netherlands, 2019; pp. 129-157.

67. Yang, J.; Kloepper, J.W.; Ryu, C.-M. Rhizosphere bacteria help plants tolerate abiotic stress. Trends Plant Sci. 2009, 14, 1-4. [CrossRef]

68. Pavlova, A.; Leontieva, M.; Smirnova, T.; Kolomeitseva, G.; Netrusov, A.; Tsavkelova, E. Colonization strategy of the endophytic plant growth-promoting strains of Pseudomonas fluorescens and Klebsiella oxytoca on the seeds, seedlings and roots of the epiphytic orchid, Dendrobium nobileLindl. J. Appl. Microbiol. 2017, 123, 217-232. [CrossRef]

69. Singh, J.S.; Singh, D.P. Plant Growth Promoting Rhizobacteria (PGPR): Microbes in Sustainable Agriculture. In Management of Microbial Resources in the Environment; Springer Science and Business Media LLC: Berlin/Heidelberg, Germany, 2013; pp. 361-385.

70. Gerhardt, K.E.; MacNeill, G.J.; Gerwing, P.D.; Greenberg, B.M. Phytoremediation of Salt-Impacted Soils and Use of Plant Growth-Promoting Rhizobacteria (PGPR) to Enhance Phytoremediation. In Phytoremediation; Springer Science and Business Media LLC: Berlin/Heidelberg, Germany, 2017; Volume 5, pp. 19-51. 
71. Agrawal, R.; Satlewal, A. Characterization of Plant Growth-Promoting Rhizobacteria (PGPR): A Perspective of Conventional Versus Recent Techniques. In Applied Bioremediation and Phytoremediation; Springer Science and Business Media LLC: Berlin/Heidelberg, Germany, 2015; Volume 44, pp. 471-485.

72. Saravanakumar, D.; Samiyappan, R. ACC deaminase from Pseudomonas fluorescens mediated saline resistance in groundnut (Arachis hypogea) plants. J. Appl. Microbiol. 2007, 102, 1283-1292. [CrossRef]

73. Lynch, J.M.; Whipps, J.M. Substrate flow in the rhizosphere. Plant Soil 1990, 129, 1-10. [CrossRef]

74. Rezazadeh, S.; Aghayari, F.; Paknejad, F.; Rezaee, M. The physiological and biochemical responses of directly seeded and transplanted maize (Zea mays L.) supplied with plant growth-promoting rhizobacteria (PGPR) under water stress. Plant Physiol. 2019, 10, 3009-3021.

75. Khan, N.; Bano, A. Role of PGPR in the Phytoremediation of Heavy Metals and Crop Growth under Municipal Wastewater Irrigation. In Phytoremediation; Springer: Cham, Switzerland, 2018; pp. 135-149.

76. Castillo, P.; Molina, R.; Andrade, A.; Vigliocco, A.; Alemano, S.; Cassán, F. Phytohormones and Other Plant Growth Regulators Produced by PGPR: The Genus Azospirillum. In Handbook for Azospirillum; Springer Science and Business Media LLC: Berlin/Heidelberg, Germany, 2015; pp. 115-138.

77. Kumar, A.; Bahadur, I.; Maurya, B.R.; Raghuwanshi, R.; Meena, V.S.; Singh, D.K.; Dixit, J. Does a plant growth-promoting rhizobacteria enhance agricultural sustainability. J. Pure Appl. Microbiol. 2015, 9, 715-724.

78. Tsukanova, K.A.; Meyer, J.J.M.; Bibikova, T.N. Effect of plant growth-promoting Rhizobacteria on plant hormone homeostasis. South Afr. J. Bot. 2017, 113, 91-102. [CrossRef]

79. Kang, S.-M.; Khan, A.L.; Waqas, M.; You, Y.-H.; Kim, J.-H.; Kim, J.-G.; Hamayun, M.; Lee, I.-J. Plant growth-promoting rhizobacteria reduce adverse effects of salinity and osmotic stress by regulating phytohormones and antioxidants in Cucumis sativus. J. Plant Interact. 2014, 9, 673-682. [CrossRef]

80. Maheshwari, D.K.; Dheeman, S.; Agarwal, M. Phytohormone-Producing PGPR for Sustainable Agriculture. In Bacterial Metabolites in Sustainable Agroecosystem; Springer Science and Business Media LLC: Berlin/Heidelberg, Germany, 2015; pp. 159-182.

81. Fard, M.D.; Habibi, D.; Fard, F.D. Effect of plant growth promoting rhizobacteria and foliar application of amino acids and silicic acid on antioxidant enzyme activity of wheat under drought stress. Chem. Eng. 2011, $23,80-85$.

82. Kurepin, L.V.; Zaman, M.; Pharis, R.P. Phytohormonal basis for the plant growth promoting action of naturally occurring biostimulators. J. Sci. Food Agric. 2014, 94, 1715-1722. [CrossRef]

83. Bhattacharyya, P.N.; Jha, D.K. Plant growth-promoting rhizobacteria (PGPR): Emergence in agriculture. World J. Microbiol. Biotechnol. 2011, 28, 1327-1350. [CrossRef] [PubMed]

84. Yoneyama, K.; Xie, X.; Kim, H.I.; Kisugi, T.; Nomura, T.; Sekimoto, H.; Yokota, T.; Yoneyama, K. How do nitrogen and phosphorus deficiencies affect strigolactone production and exudation? Planta 2012, 235, 1197-1207. [CrossRef]

85. Yin, C.; Park, J.-J.; Gang, D.R.; Hulbert, S.H. Characterization of a Tryptophan 2-Monooxygenase Gene from Puccinia graminis f. sp. tritici Involved in Auxin Biosynthesis and Rust Pathogenicity. Mol. Plant-Microbe Interact. 2014, 27, 227-235. [CrossRef]

86. Duca, D.; Lorv, J.; Patten, C.L.; Rose, D.; Glick, B.R. Indole-3-acetic acid in plant-microbe interactions. Antonie van Leeuwenhoek 2014, 106, 85-125. [CrossRef]

87. Barash, I.; Manulis-Sasson, S. Recent Evolution of Bacterial Pathogens: The Gall-FormingPantoea agglomeransCase. Annu. Rev. Phytopathol. 2009, 47, 133-152. [CrossRef]

88. Crépin, A.; Barbey, C.; Beury-Cirou, A.; Hélias, V.; Taupin, L.; Reverchon, S.; Nasser, W.; Faure, D.; Dufour, A.; Orange, N.; et al. Quorum Sensing Signaling Molecules Produced by Reference and Emerging Soft-Rot Bacteria (Dickeya and Pectobacterium spp.). PLoS ONE 2012, 7, e35176. [CrossRef]

89. Aragón, I.M.; Pérez-Martínez, I.; Moreno-Pérez, A.; Cerezo, M.; Ramos, C. New insights into the role of indole-3-acetic acid in the virulence ofPseudomonas savastanoipv.savastanoi. FEMS Microbiol. Lett. 2014, 356, 184-192. [CrossRef]

90. McClerklin, S.; Lee, S.G.; Harper, C.P.; Nwumeh, R.; Jez, J.M.; Kunkel, B.N. Pseudomonas syringae DC3000-derived auxin contributes to virulence on Arabidopsis. PLoS Path. 2018, 14, e1006811. [CrossRef]

91. Broek, A.V.; Gysegom, P.; Ona, O.; Hendrickx, N.; Prinsen, E.; Van Impe, J.; Vanderleyden, J. Transcriptional Analysis of the Azospirillum brasilense Indole-3-Pyruvate Decarboxylase Gene and Identification of a cis-Acting Sequence Involved in Auxin Responsive Expression. Mol. Plant-Microbe Interact. 2005, 18, 311-323. [CrossRef] 
92. Van Puyvelde, S.; Cloots, L.; Engelen, K.; Das, F.; Marchal, K.; Vanderleyden, J.; Spaepen, S. Transcriptome Analysis of the Rhizosphere Bacterium Azospirillum brasilense Reveals an Extensive Auxin Response. Microb. Ecol. 2011, 61, 723-728. [CrossRef]

93. Donati, A.J.; Lee, H.-I.; Leveau, J.H.J.; Chang, W.-S. Effects of Indole-3-Acetic Acid on the Transcriptional Activities and Stress Tolerance of Bradyrhizobium japonicum. PLoS ONE 2013, 8, e76559. [CrossRef]

94. Vandana, U.K.; Singha, B.; Gulzar, A.; Mazumder, P. Molecular mechanisms in plant growth promoting bacteria (PGPR) to resist environmental stress in plants. In Molecular Aspects of Plant Beneficial Microbes in Agriculture; Elsevier BV: Amsterdam, The Netherlands, 2020; pp. 221-233.

95. Ghosh, D.; Gupta, A.; Mohapatra, S. Dynamics of endogenous hormone regulation in plants by phytohormone secreting rhizobacteria under water-stress. Symbiosis 2018, 77, 265-278. [CrossRef]

96. Galván, M.; Eduardo, A.; Cortés-Patiño, S.; Romero-Perdomo, F.; Uribe-Vélez, D.; Bashan, Y.; Bonilla, R.R. Proline accumulation and glutathione reductase activity induced by drought-tolerant rhizobacteria as potential mechanisms to alleviate drought stress in Guinea grass. Appl. Soil Ecol. 2020, 147, 103367. [CrossRef]

97. Shivakumar, S.; Bhaktavatchalu, S. Role of Plant Growth-Promoting Rhizobacteria (PGPR) in the Improvement of Vegetable Crop Production Under Stress Conditions. In Microbial Strategies for Vegetable Production; Springer Science and Business Media LLC: Berlin/Heidelberg, Germany, 2017; pp. 81-97.

98. Puga-Freitas, R.; Blouin, M. A review of the effects of soil organisms on plant hormone signalling pathways. Environ. Exp. Bot. 2015, 114, 104-116. [CrossRef]

99. Ali, S.; Khan, N.; Nouroz, F.; Erum, S.; Nasim, W.; Shahid, M.A. In vitro effects of GA3 on morphogenesis of CIP potato explants and acclimatization of plantlets in field. Invitro. Cell. Dev. Biol.-Plant 2018, 54, 104-111. [CrossRef]

100. Naseri, R.; Maleki, A.; Naserirad, H.; Shebibi, S.; Omidian, A. Effect of plant growth promoting rhizobacteria (PGPR) on reduction nitrogen fertilizer application in rapeseed (Brassica napus L.). Middle-East J. Sci. Res. 2013, 14, 213-220.

101. Baxter, H.L.; Stewart, C.N. Effects of altered lignin biosynthesis on phenylpropanoid metabolism and plant stress. Biofuels 2013, 4, 635-650. [CrossRef]

102. Prasad, R.; Kumar, M.; Varma, A. Role of PGPR in Soil Fertility and Plant Health. In Applied Bioremediation and Phytoremediation; Springer Science and Business Media LLC: Berlin/Heidelberg, Germany, 2014; pp. 247-260.

103. Ranty, B.; Aldon, D.; Cotelle, V.; Galaud, J.-P.; Thuleau, P.; Mazars, C. Calcium Sensors as Key Hubs in Plant Responses to Biotic and Abiotic Stresses. Front. Plant Sci. 2016, 7, 327. [CrossRef]

104. Sgroy, V.; Cassán, F.; Masciarelli, O.; Del Papa, M.F.; Lagares, A.; Luna, V. Isolation and characterization of endophytic plant growth-promoting (PGPB) or stress homeostasis-regulating (PSHB) bacteria associated to the halophyte Prosopis strombulifera. Appl. Microbiol. Biotechnol. 2009, 85, 371-381. [CrossRef]

105. Mazumdar, D.; Saha, S.P.; Ghosh, S. Isolation, screening and application of a potent PGPR for enhancing growth of Chickpea as affected by nitrogen level. Int. J. Veg. Sci. 2019, 26, 333-350. [CrossRef]

106. Ali, S.; Charles, T.C.; Glick, B.R. Amelioration of high salinity stress damage by plant growth-promoting bacterial endophytes that contain ACC deaminase. Plant Physiol. Biochem. 2014, 80, 160-167. [CrossRef] [PubMed]

107. Khan, N.; Bano, A. Exopolysaccharide producing rhizobacteria and their impact on growth and drought tolerance of wheat grown under rainfed conditions. PLoS ONE 2019, 14, e222302. [CrossRef]

108. Atieno, M.; Herrmann, L.; Nguyen, H.T.; Phan, H.T.; Nguyen, N.K.; Srean, P.; Than, M.M.; Zhiyong, R.; Tittabutr, P.; Shutsrirung, A.; et al. Assessment of biofertilizer use for sustainable agriculture in the Great Mekong Region. J. Environ. Manag. 2020, 275, 111300. [CrossRef] [PubMed]

109. Alkahtani, M.D.F.; Attia, K.A.; Hafez, Y.M.; Khan, N.; Eid, A.M.; Ali, M.A.M.; Abdelaal, K.A.A. Chlorophyll Fluorescence Parameters and Antioxidant Defense System Can Display Salt Tolerance of Salt Acclimated Sweet Pepper Plants Treated with Chitosan and Plant Growth Promoting Rhizobacteria. Agronomy 2020, 10, 1180. [CrossRef]

110. Urano, K.; Yoshiba, Y.; Nanjo, T.; Igarashi, Y.; Seki, M.; Sekiguchi, F.; Yamaguchi-Shinozaki, K. Characterization of Arabidopsis genes involved in biosynthesis of polyamines in abiotic stress responses and developmental stages. Plant Cell Environ. 2003, 26, 1917-1926. [CrossRef]

111. Rahdari, P.; Tavakoli, S.; Hosseini, S.M. Studying of salinity stress effect on germination, proline, sugar, protein, lipid and chlorophyll content in purslane (Portulaca oleracea L.) leaves. J. Stress Physiol. Biochem. 2012, 8, 182-193. 
112. Gusain, Y.S.; Singh, U.S.; Sharma, A.K. Bacterial mediated amelioration of drought stress in drought tolerant and susceptible cultivars of rice (Oryza sativa L.). Afr. J. Biotechnol. 2015, 14, 764-773.

113. Vurukonda, S.S.K.P.; Vardharajula, S.; Shrivastava, M.; SkZ, A. Enhancement of drought stress tolerance in crops by plant growth promoting rhizobacteria. Microbiol. Res. 2016, 184, 13-24. [CrossRef]

114. Kumari, S.; Vaishnav, A.; Jain, S.; Varma, A.; Choudhary, D.K. Bacterial-mediated induction of systemic tolerance to salinity with expression of stress alleviating enzymes in soybean (Glycine max L. Merrill). J. Plant Growth Regul. 2015, 34, 558-573. [CrossRef]

115. Gou, W.; Tian, L.; Ruan, Z.; Zheng, P.E.N.G.; Chen, F.U.C.A.I.; Zhang, L.; Shi, W. Accumulation of choline and glycinebetaine and drought stress tolerance induced in maize (Zea mays) by three plant growth promoting rhizobacteria (PGPR) strains. Pak J. Bot. 2015, 47, 581-586.

116. Vigani, G.; Rolli, E.; Marasco, R.; Dell'Orto, M.; Michoud, G.; Soussi, A.; Daffonchio, D. Root bacterial endophytes confer drought resistance and enhance expression and activity of a vacuolar H+-pumping pyrophosphatase in pepper plants. Environ. Microbiol. 2019, 21, 3212-3228. [CrossRef]

117. SkZ, A.; Vardharajula, S.; Vurukonda, S.S.K.P. Transcriptomic profiling of maize (Zea mays L.) seedlings in response to Pseudomonas putida stain FBKV2 inoculation under drought stress. Ann. Microbiol. 2018, 68, 331-349. [CrossRef]

118. Lugtenberg, B.; Kamilova, F. Plant-growth-promoting rhizobacteria. Annu. Rev. Microbiol. 2009, 63, 541-556. [CrossRef] [PubMed]

119. Vílchez, J.I.; García-Fontana, C.; Román-Naranjo, D.; González-López, J.; Manzanera, M. Plant drought tolerance enhancement by trehalose production of desiccation-tolerant microorganisms. Front. Microbiol. 2016, 7, 1577. [CrossRef] [PubMed]

120. Basra, S.M.; Lovatt, C.J. Exogenous Applications of Moringa Leaf Extract and Cytokinins Improve Plant Growth, Yield, and Fruit Quality of Cherry Tomato. HortTechnology 2016, 26, 327-337. [CrossRef]

121. Less, H.; Egalili, G. Principal Transcriptional Programs Regulating Plant Amino Acid Metabolism in Response to Abiotic Stresses. Plant Physiol. 2008, 147, 316-330. [CrossRef] [PubMed]

122. Jaleel, C.A.; Manivannan, P.; Sankar, B.; Kishorekumar, A.; Gopi, R.; Somasundaram, R.; Panneerselvam, R. Pseudomonas fluorescens enhances biomass yield and ajmalicine production in Catharanthus roseus under water deficit stress. Colloids Surfaces B Biointerfaces 2007, 60, 7-11. [CrossRef]

123. Saakre, M.; Baburao, T.M.; Salim, A.P.; Ffancies, R.M.; Achuthan, V.P.; Thomas, G.; Sivarajan, S.R. Identification and Characterization of Genes Responsible for Drought Tolerance in Rice Mediated by Pseudomonas fluorescens. Rice Sci. 2017, 24, 291-298. [CrossRef]

124. Khan, N.; Ali, S.; Shahid, M.A.; Kharabian-Masouleh, A. Advances in detection of stress tolerance in plants through metabolomics approaches. Plant Omics 2017, 10, 153-163. [CrossRef]

125. Furlan, A.L.; Bianucci, E.; Castro, S.; Dietz, K.-J. Metabolic features involved in drought stress tolerance mechanisms in peanut nodules and their contribution to biological nitrogen fixation. Plant Sci. 2017, 263, 12-22. [CrossRef]

126. Bounedjah, O.; Hamon, L.; Savarin, P.; Desforges, B.; Curmi, P.A.; Pastré, D. Macromolecular Crowding Regulates Assembly of mRNA Stress Granules after Osmotic Stress new role for compatible osmolytes. J. Biol. Chem. 2012, 287, 2446-2458. [CrossRef]

127. Selvakumar, G.; Panneerselvam, P.; Ganeshamurthy, A.N. Bacterial Mediated Alleviation of Abiotic Stress in Crops. In Bacteria in Agrobiology: Stress Management; Springer: Berlin/Heidelberg, Germany, 2012; pp. $205-224$.

128. Su, Z.; Yacob, A.; Wen, J.; Roerink, G.; He, Y.; Gao, B.; Boogaard, H.; Van Diepen, C. Assessing relative soil moisture with remote sensing data: Theory, experimental validation, and application to drought monitoring over the North China Plain. Phys. Chem. Earth Parts A/B/C 2003, 28, 89-101. [CrossRef]

129. Ansari, F.A.; Ahmad, I. Biofilm Development, Plant Growth Promoting Traits and Rhizosphere Colonization by Pseudomonas entomophila FAP1: A Promising PGPR. Adv. Microbiol. 2018, 8, 235-251. [CrossRef]

130. Khan, N.; Bano, A. Growth and Yield of Field Crops Grown Under Drought Stress Condition Is Influenced by the Application of PGPR. In Field Crops: Sustainable Management by PGPR; Springer: Cham, Switzerland, 2019; pp. 337-349.

131. Singh, A.; Chauhan, P.S. Ecological Significance of Soil-Associated Plant Growth-Promoting Biofilm-Forming Microbes for Stress Management. In Biofilms in Plant and Soil Health; Wiley: Hoboken, NJ, USA, 2017; pp. 291-326. 
132. Alami, Y.; Achouak, W.; Marol, C.; Heulin, T. Rhizosphere Soil Aggregation and Plant Growth Promotion of Sunflowers by an Exopolysaccharide-Producing Rhizobiumsp. Strain Isolated from Sunflower Roots. Appl. Environ. Microbiol. 2000, 66, 3393-3398. [CrossRef] [PubMed]

133. Bramhachari, P.V.; Nagaraju, G.P.; Kariali, E. Current Perspectives on Rhizobacterial-EPS interactions in Alleviation of Stress Responses: Novel Strategies for Sustainable Agricultural Productivity. In Role of Rhizospheric Microbes in Soil; Springer Science and Business Media LLC: Berlin/Heidelberg, Germany, 2018; pp. 33-55.

134. Khan, N.; Bano, A. Modulation of phytoremediation and plant growth by the treatment with PGPR, Ag nanoparticle and untreated municipal wastewater. Int. J. Phytoremediat. 2016, 18, 1258-1269. [CrossRef]

135. Gontia-Mishra, I.; Sapre, S.; Kachare, S.; Tiwari, S. Molecular diversity of 1-aminocyclopropane-1-carboxylate (ACC) deaminase producing PGPR from wheat (Triticum aestivum L.) rhizosphere. Plant Soil 2016, 414, 213-227. [CrossRef]

136. Timmusk, S.; Timmusk, K.; Behers, L. Rhizobacterial plant drought stress tolerance enhancement: Towards sustainable water resource management and food security. J. Food Secur. 2013, 1, 6-9.

137. Bogino, P.; Abod, A.; Nievas, F.; Giordano, W. Water-Limiting Conditions Alter the Structure and Biofilm-Forming Ability of Bacterial Multispecies Communities in the Alfalfa Rhizosphere. PLoS ONE 2013, 8, e79614. [CrossRef]

138. Kovács, Á.T.; Dragoš, A. Evolved Biofilm: Review on the Experimental Evolution Studies of Bacillus subtilis Pellicles. J. Mol. Biol. 2019, 431, 4749-4759. [CrossRef]

139. Gauri, S.S.; Mandal, S.M.; Pati, B.R. Impact of Azotobacter exopolysaccharides on sustainable agriculture. Appl. Microbiol. Biotechnol. 2012, 95, 331-338. [CrossRef]

140. Banerjee, A.; Sarkar, S.; Cuadros-Orellana, S.; Bandopadhyay, R. Exopolysaccharides and Biofilms in Mitigating Salinity Stress: The Biotechnological Potential of Halophilic and Soil-Inhabiting PGPR Microorganisms. In Microorganisms in Saline Environments: Strategies and Functions; Springer: Cham, Switzerland, 2019; pp. 133-153.

141. Din, B.U.; Sarfraz, S.; Xia, Y.; Kamran, M.A.; Javed, M.T.; Sultan, T.; Munis, M.F.H.; Chaudhary, H.J. Mechanistic elucidation of germination potential and growth of wheat inoculated with exopolysaccharide and ACC- deaminase producing Bacillus strains under induced salinity stress. Ecotoxicol. Environ. Saf. 2019, 183, 109466. [CrossRef]

142. Arshad, M.; Shaharoona, B.; Mahmood, T. Inoculation with Pseudomonas spp. Containing ACC-Deaminase Partially Eliminates the Effects of Drought Stress on Growth, Yield, and Ripening of Pea (Pisum sativum L.). Pedosphere 2008, 18, 611-620. [CrossRef]

143. Gupta, G.; Snehi, S.K.; Singh, V. Role of PGPR in Biofilm Formations and Its Importance in Plant Health. Biofilms Plant Soil Health 2017, 27, 27-42. [CrossRef]

144. Chen, L.; Dodd, I.C.; Theobald, J.C.; Belimov, A.A.; Davies, W.J. The rhizobacterium Variovorax paradoxus $5 \mathrm{C}-2$, containing ACC deaminase, promotes growth and development of Arabidopsis thaliana via an ethylene-dependent pathway. J. Exp. Bot. 2013, 64, 1565-1573. [CrossRef]

145. Zahir, Z.A.; Munir, A.; Asghar, H.N.; Shaharoona, B.; Arshad, M. Effectiveness of rhizobacteria containing ACC deaminase for growth promotion of peas (Pisum sativum) under drought conditions. J. Microbiol. Biotechnol. 2008, 18, 958-963.

146. Belimov, A.A.; Dodd, I.C.; Hontzeas, N.; Theobald, J.C.; Safronova, V.I.; Davies, W.J. Rhizosphere bacteria containing 1-aminocyclopropane-1-carboxylate deaminase increase yield of plants grown in drying soil via both local and systemic hormone signalling. New Phytol. 2009, 181, 413-423. [CrossRef]

147. Sharma, P.; Khanna, V.; Kumari, P. Efficacy of aminocyclopropane-1-carboxylic acid (ACC)-deaminase-producing rhizobacteria in ameliorating water stress in chickpea under axenic conditions. Afr. J. Microbiol. Res. 2013, 7, 5749-5757.

148. Ghosh, D.; Gupta, A.; Mohapatra, S. A comparative analysis of exopolysaccharide and phytohormone secretions by four drought-tolerant rhizobacterial strains and their impact on osmotic-stress mitigation in Arabidopsis thaliana. World J. Microbiol. Biotechnol. 2019, 35, 90. [CrossRef]

149. Kousar, B.; Bano, A.; Khan, N. PGPR Modulation of Secondary Metabolites in Tomato Infested with Spodoptera litura. Agronomy 2020, 10, 778. [CrossRef] 
150. Bessadok, K.; Navarro-Torre, S.; Pajuelo, E.; Mateos-Naranjo, E.; Redondo-Gómez, S.; Caviedes, M.Á.; Fterich, A.; Mars, M.; Rodríguez-Llorente, I.D. The ACC-Deaminase Producing Bacterium Variovorax sp. CT7.15 as a Tool for Improving Calicotome villosa Nodulation and Growth in Arid Regions of Tunisia. Microorganisms 2020, 8, 541. [CrossRef]

151. Arora, N.K.; Fatima, T.; Mishra, J.; Mishra, I.; Verma, S.; Verma, R.; Verma, M.; Bhattacharya, A.; Verma, P.; Mishra, P.; et al. Halo-tolerant plant growth promoting rhizobacteria for improving productivity and remediation of saline soils. J. Adv. Res. 2020, 26, 69-82. [CrossRef]

152. Grover, M.; Ali, S.Z.; Sandhya, V.; Rasul, A.; Venkateswarlu, B. Role of microorganisms in adaptation of agriculture crops to abiotic stresses. World J. Microbiol. Biotechnol. 2011, 27, 1231-1240. [CrossRef]

153. Upadhyay, S.K.; Singh, J.; Singh, D. Exopolysaccharide-Producing Plant Growth-Promoting Rhizobacteria under Salinity Condition. Pedosphere 2011, 21, 214-222. [CrossRef]

154. Scandalios, J.G. Regulation and Properties of Plant Catalases. In Causes of Photooxidative Stress and Amelioration of Defense Systems in Plants; CRC Press: Boca Raton, FL, USA, 2019; pp. 275-316.

155. Murphy, D.V.; Stockdale, E.A.; Brookes, P.C.; Goulding, K. Impact of Microorganisms on Chemical Transformations in Soil. In Soil Biological Fertility; Springer Science and Business Media LLC: Berlin/Heidelberg, Germany, 2007; pp. 37-59.

156. Abawi, G.; Widmer, T. Impact of soil health management practices on soilborne pathogens, nematodes and root diseases of vegetable crops. Appl. Soil Ecol. 2000, 15, 37-47. [CrossRef]

157. Bowler, C.; Montagu, M.V.; Inze, D. Superoxide dismutase and stress tolerance. Ann. Rev. Plant Physiol. Mol. Biol. 1992, 43, 83-116. [CrossRef]

158. Shahid, M.A.; Sarkhosh, A.; Khan, N.; Balal, R.M.; Ali, S.; Rossi, L.; Gómez, C.; Mattson, N.; Nasim, W.; Garcia-Sanchez, F. Insights into the Physiological and Biochemical Impacts of Salt Stress on Plant Growth and Development. Agronomy 2020, 10, 938. [CrossRef]

159. Deng, Y.; Chen, C.; Zhao, Z.; Zhao, J.; Jacq, A.; Huang, X.; Yang, Y. The RNA Chaperone Hfq Is Involved in Colony Morphology, Nutrient Utilization and Oxidative and Envelope Stress Response in Vibrio alginolyticus. PLoS ONE 2016, 11, e0163689. [CrossRef]

160. Guterman, L. Distortions to Agricultural Incentives in Colombia; Agricultural Distortions Working Paper Series No. 1856-2016-152637; Word Bank, December 2007. Available online: https://ideas.repec.org/p/ags/wbadwp/ 48392.html (accessed on 5 September 2020).

161. Mayak, S.; Tirosh, T.; Glick, B.R. Plant growth-promoting bacteria that confer resistance to water stress in tomatoes and peppers. Plant Sci. 2004, 166, 525-530. [CrossRef]

162. Qureshi, M.A.; Iqbal, A.; Akhtar, N.; Shakir, M.A.; Khan, A. Co-inoculation of phosphate solubilizing bacteria and rhizobia in the presence of L-tryptophan for the promotion of mash bean (Vigna mungo L.). Soil Environ. 2012, 31, 47-54.

163. Saikia, J.; Sarma, R.K.; Dhandia, R.; Yadav, A.; Bharali, R.; Gupta, V.K.; Saikia, R. Alleviation of drought stress in pulse crops with ACC deaminase producing rhizobacteria isolated from acidic soil of Northeast India. Sci. Rep. 2018, 8, 1-16. [CrossRef]

164. Zhu, M.-L.; Wu, X.-Q.; Wang, Y.-H.; Dai, Y. Role of Biofilm Formation by Bacillus pumilus HR10 in Biocontrol against Pine Seedling Damping-Off Disease Caused by Rhizoctonia solani. Forest 2020, 11, 652. [CrossRef]

165. Rana, K.L.; Kour, D.; Yadav, A.N.; Yadav, N.; Saxena, A.K. Agriculturally important microbial biofilms: Biodiversity, ecological significances, and biotechnological applications. In New and Future Developments in Microbial Biotechnology and Bioengineering: Microbial Biofilms; Elsevier BV: Amsterdam, The Netherlands, 2020; pp. 221-265.

166. Cohen, A.C.; Bottini, R.; Piccoli, P. Role of Abscisic Acid Producing PGPR in Sustainable Agriculture. In Sustainable Development and Biodiversity; Springer Science and Business Media LLC: Berlin/Heidelberg, Germany, 2015; pp. 259-282.

167. Kalam, S.; Basu, A.; Ankati, S. Plant Root-Associated Biofilms in Bioremediation. Biofilms Plant Soil Health 2017, 337, 337-355. [CrossRef]

168. Sarma, B.K.; Yadav, S.K.; Singh, D.P.; Singh, H.B. Rhizobacteria mediated induced systemic tolerance in plants: Prospects for abiotic stress management. In Bacteria in Agrobiology: Stress Management; Springer: Berlin/Heidelberg, Germany, 2012; pp. 225-238. 
169. Primo, E.D.; Ruiz, F.; Masciarelli, O.; Giordano, W. Biofilm Formation and Biosurfactant Activity in Plant-Associated Bacteria. In Sustainable Development and Biodiversity; Springer Science and Business Media LLC: Berlin/Heidelberg, Germany, 2015; Volume 12, pp. 337-349.

170. Kour, D.; Rana, K.L.; Kaur, T.; Yadav, N.; Yadav, A.N.; Rastegari, A.A.; Saxena, A.K. Microbial biofilms: Functional annotation and potential applications in agriculture and allied sectors. In New and Future Developments in Microbial Biotechnology and Bioengineering: Microbial Biofilms; Elsevier BV: Amsterdam, The Netherlands, 2020; pp. 283-301.

171. Khan, N.; Zandi, P.; Ali, S.; Mehmood, A.; Shahid, M.A.; Yang, J. Impact of Salicylic Acid and PGPR on the Drought Tolerance and Phytoremediation Potential of Helianthus annus. Front. Microbiol. 2018, 9, 2507. [CrossRef]

172. Gupta, S.; Pandey, S. Unravelling the biochemistry and genetics of ACC deaminase-An enzyme alleviating the biotic and abiotic stress in plants. Plant Gene 2019, 18, 100175. [CrossRef]

173. Selvakumar, G.; Bhatt, R.M.; Upreti, K.K.; Bindu, G.H.; Shweta, K. Citricoccus zhacaiensis B-4 (MTCC 12119) a novel osmotolerant plant growth promoting actinobacterium enhances onion (Allium cepa L.) seed germination under osmotic stress conditions. World J. Microbiol. Biotechnol. 2015, 31, 833-839. [CrossRef]

174. Kim, S.-G.; Kim, S.-Y.; Park, C.-M. A membrane-associated NAC transcription factor regulates salt-responsive flowering via FLOWERING LOCUS T in Arabidopsis. Planta 2007, 226, 647-654. [CrossRef]

175. Marulanda, A.; Porcel, R.; Barea, J.M.; Azcón, R. Drought Tolerance and Antioxidant Activities in Lavender Plants Colonized by Native Drought-tolerant or Drought-sensitive Glomus Species. Microb. Ecol. 2007, 54, 543-552. [CrossRef]

176. Vu, B.; Chen, M.; Crawford, R.J.; Ivanova, E.P. Bacterial Extracellular Polysaccharides Involved in Biofilm Formation. Molecules 2009, 14, 2535-2554. [CrossRef]

177. Barriuso, J.; Ramos-Solano, B.; Lucas, J.A.; Lobo, A.P.; Garca-Villaraco, A.; Maero, F.J.G.; García-Villaraco, A.; Gutierrez-Mañero, F.J. Ecology, Genetic Diversity and Screening Strategies of Plant Growth Promoting Rhizobacteria (PGPR). Plant-Bact. Interact. 2008, 4, 1-17. [CrossRef]

178. Chen, S.; Zhao, H.; Zou, C.; Li, Y.; Chen, Y.; Wang, Z.; Jiang, Y.; Liu, A.; Zhao, P.; Wang, M.; et al. Combined Inoculation with Multiple Arbuscular Mycorrhizal Fungi Improves Growth, Nutrient Uptake and Photosynthesis in Cucumber Seedlings. Front. Microbiol. 2017, 8, 2516. [CrossRef]

179. Colinet, H.; Larvor, V.; Laparie, M.; Renault, D. Exploring the plastic response to cold acclimation through metabolomics. Funct. Ecol. 2012, 26, 711-722. [CrossRef]

180. Glick, B.R. The enhancement of plant growth by free-living bacteria. Can. J. Microbiol. 1995, 41, 109-117. [CrossRef]

181. Kloepper, J.W.; Lifshitz, R.; Zablotowicz, R.M. Free-living bacterial inocula for enhancing crop productivity. Trends Biotechnol. 1989, 7, 39-44. [CrossRef]

182. Rahdari, P.; Hoseini, S.M. Drought stress: A review. Int. J. Agron. Plant Prod. 2012, 3, 443-446.

183. Shafeek, M.R.; Helmy, Y.I.; Omar, N.M. Use of some bio-stimulants for improving the growth, yield and bulb quality of onion plants (Allium cepa L.) under sandy soil conditions. Middle East J. Appl. Sci. 2015, 5, 68-75.

184. Nelson, L.M. Plant Growth Promoting Rhizobacteria (PGPR): Prospects for New Inoculants. Crop Manag. 2004, 3, 1-7. [CrossRef]

185. Kumar, A.; Prakash, A.; Johri, B.N. Bacillus as PGPR in Crop Ecosystem. In Bacteria in Agrobiology: Crop Ecosystems; Springer Science and Business Media LLC: Berlin/Heidelberg, Germany, 2011; pp. $37-59$.

186. Singh, G.G.S. Plant Growth Promoting Rhizobacteria (PGPR): Current and Future Prospects for Development of Sustainable Agriculture. J. Microb. Biochem. Technol. 2015, 7, 096-102. [CrossRef]

187. Khan, N.; Ebano, A. Role of plant growth promoting rhizobacteria and Ag-nano particle in the bioremediation of heavy metals and maize growth under municipal wastewater irrigation. Int. J. Phytoremediat. 2015, 18, 211-221. [CrossRef]

188. Arora, N.K.; Tewari, S.; Singh, S.; Lal, N.; Maheshwari, D.K. PGPR for protection of plant health under saline conditions. In Bacteria in Agrobiology: Stress Management; Springer: Berlin/Heidelberg, Germany, 2012; pp. 239-258.

189. Sharma, I.P.; Chandra, S.; Kumar, N.; Chandra, D. PGPR: Heart of Soil and Their Role in Soil Fertility. In Agriculturally Important Microbes for Sustainable Agriculture; Springer Science and Business Media LLC: Berlin/Heidelberg, Germany, 2017; pp. 51-67. 
190. Costa, O.Y.A.; Raaijmakers, J.M.; Kuramae, E.E. Microbial Extracellular Polymeric Substances: Ecological Function and Impact on Soil Aggregation. Front. Microbiol. 2018, 9, 1636. [CrossRef]

191. Chenu, C. Clay- or sand-polysaccharide associations as models for the interface between micro-organisms and soil: Water related properties and microstructure. Geoderma 1993, 56, 143-156. [CrossRef]

192. Cheynier, V.; Comte, G.; Davies, K.M.; Lattanzio, V.; Martens, S. Plant phenolics: Recent advances on their biosynthesis, genetics, and ecophysiology. Plant Physiol. Biochem. 2013, 72, 1-20. [CrossRef]

193. Durán, P.; Acuña, J.; Armada, E.; López-Castillo, O.; Cornejo, P.; Mora, M.; Azcón, R. Inoculation with selenobacteria and arbuscular mycorrhizal fungi to enhance selenium content in lettuce plants and improve tolerance against drought stress. J. Soil Sci. Plant Nutr. 2016, 16, 211-225. [CrossRef]

194. Nakashima, K.; Ito, Y.; Yamaguchi-Shinozaki, K. Transcriptional Regulatory Networks in Response to Abiotic Stresses in Arabidopsis and Grasses: Figure 1. Plant Physiol. 2009, 149, 88-95. [CrossRef] [PubMed]

195. Zhu, J.-K. Abiotic Stress Signaling and Responses in Plants. Cell 2016, 167, 313-324. [CrossRef] [PubMed]

196. Wang, M.; Li, P.; Li, C.; Pan, Y.; Jiang, X.; Zhu, D.; Zhao, Q.; Yu, J. SiLEA14, a novel atypical LEA protein, confers abiotic stress resistance in foxtail millet. BMC Plant Biol. 2014, 14, 290. [CrossRef] [PubMed]

197. Takahashi, F.; Shinozaki, K. Long-distance signaling in plant stress response. Curr. Opin. Plant Biol. 2019, 47, 106-111. [CrossRef]

198. Ali, S.; Hayat, K.; Iqbal, A.; Xie, L. Implications of Abscisic Acid in the Drought Stress Tolerance of Plants. Agronomy 2020, 10, 1323. [CrossRef]

199. Khan, N.; Bano, A.; Zandi, P. Effects of exogenously applied plant growth regulators in combination with PGPR on the physiology and root growth of chickpea (Cicer arietinum) and their role in drought tolerance. J. Plant Interact. 2018, 1, 239-247. [CrossRef]

200. Zong, N.; Wang, H.; Li, Z.; Ma, L.; Xie, L.; Pang, J.; Fan, Y.; Zhao, J. Maize NCP1 negatively regulates drought and ABA responses through interacting with and inhibiting the activity of transcription factor ABP9. Plant Mol. Biol. 2020, 102, 339-357. [CrossRef]

201. Wang, D.; Pan, Y.; Zhao, X.; Zhu, L.; Fu, B.; Li, Z. Genome-wide temporal-spatial gene expression profiling of drought responsiveness in rice. BMC Genom. 2011, 12, 149. [CrossRef]

202. Kasual, M. Microbes in cahoots with plants: MIST to hit the jackpot of agricultural productivity during drought. Int. J. Mol. Sci. 2019, 20, 1769.

203. Wang, Y.; Ohara, Y.; Nakayashiki, H.; Tosa, Y.; Mayama, S. Microarray Analysis of the Gene Expression Profile Induced by the Endophytic Plant Growth-Promoting Rhizobacteria, Pseudomonas fluorescens FPT9601-T5 in Arabidopsis. Mol. Plant-Microbe Interact. 2005, 18, 385-396. [CrossRef]

204. Wu, Y.; Ma, L.; Liu, Q.; Vestergård, M.; Topalovic, O.; Wang, Q.; Feng, Y. The plant-growth promoting bacteria promote cadmium uptake by inducing a hormonal crosstalk and lateral root formation in a hyperaccumulator plant Sedum alfredii. J. Hazard. Mater. 2020, 395, 122661. [CrossRef] [PubMed]

205. Urano, K.; Kurihara, Y.; Seki, M.; Shinozaki, K. 'Omics' analyses of regulatory networks in plant abiotic stress responses. Curr. Opin. Plant Biol. 2010, 13, 132-138. [CrossRef] [PubMed]

206. Mhlongo, M.I.; Piater, L.A.; Madala, N.E.; Labuschagne, N.; Dubery, I.A. The Chemistry of Plant-Microbe Interactions in the Rhizosphere and the Potential for Metabolomics to Reveal Signaling Related to Defense Priming and Induced Systemic Resistance. Front. Plant Sci. 2018, 9, 112. [CrossRef] [PubMed]

207. Meena, K.K.; Sorty, A.M.; Bitla, U.M.; Choudhary, K.; Gupta, P.; Pareek, A.; Singh, D.P.; Prabha, R.; Sahu, P.K.; Gupta, V.K.; et al. Abiotic Stress Responses and Microbe-Mediated Mitigation in Plants: The Omics Strategies. Front. Plant Sci. 2017, 8, 172. [CrossRef]

208. Khan, N.; Bano, A.; Curá, J.A. Role of Beneficial Microorganisms and Salicylic Acid in Improving Rainfed Agriculture and Future Food Safety. Microorganisms 2020, 8, 1018. [CrossRef]

Publisher's Note: MDPI stays neutral with regard to jurisdictional claims in published maps and institutional affiliations.

(C) 2020 by the authors. Licensee MDPI, Basel, Switzerland. This article is an open access article distributed under the terms and conditions of the Creative Commons Attribution (CC BY) license (http://creativecommons.org/licenses/by/4.0/). 